NOTICE: This is the author's version of a work that was accepted for publication in Journal of Structural Geology. Changes resulting from the publishing process, such as peer review, editing, corrections, structural formatting, and other quality control mechanisms may not be reflected in this document. Changes may have been made to this work since it was submitted for publication. A definitive version was subsequently published in Journal of Structural Geology [32, 2, 2010] DOI 10.1016/j.jsg.2009.11.008 


\section{Present-Day Stress Orientation in Thailand's Basins}

2 Mark R. P. Tingay ${ }^{1} *$, Chris K. Morley ${ }^{2}$, Richard R. Hillis ${ }^{3}$, Jeremy Meyer ${ }^{4}$

$3{ }^{1}$ Department of Applied Geology, Curtin University of Technology, WA, Australia.

$4 *$ Corresponding author. Tel.: +61 89266 7097; fax: +61 89266 3153, Email address:

$5 \quad$ m.tingay@curtin.edu.au

$6 \quad{ }^{2}$ PTT Exploration and Production, Bangkok, Thailand.

$7 \quad{ }^{3}$ Australian School of Petroleum, University of Adelaide, Adelaide, Australia.

$8 \quad{ }^{4}$ JRS Petroleum Research, Adelaide, Australia.

10 Abstract

11 The Cenozoic tectonic evolution of Thailand is widely considered to have been primarily

12 controlled by forces generated at the eastern Himalayan syntaxis. This hypothesis is supported by

13 earthquakes in northern Indochina and southern China, which reveal a fan shaped present-day

14 maximum horizontal stress $\left(\mathrm{S}_{\mathrm{H} \max }\right)$ pattern centered on the eastern Himalayan syntaxis. However,

15 the distance to which forces generated by the Himalayan syntaxis influence the stress pattern in

16 Indochina is not known. We analyzed caliper and image logs from 106 petroleum wells for

17 borehole breakouts and drilling-induced fractures. A total of 558 breakouts and 45 drilling-

18 induced fractures were interpreted in six basins, indicating that a north-south regional present-

19 day $\mathrm{S}_{\mathrm{Hmax}}$ exists in central and southern Thailand and the Gulf of Thailand. The N-S $\mathrm{S}_{\mathrm{Hmax}}$

20 orientation suggests that forces generated at the Himalayan syntaxis are a major control on the

21 stress pattern throughout Thailand, extending approximately $1000 \mathrm{~km}$ beyond the outer limit of

22 syntaxis-associated seismicity. Despite the influence of the Himalayan syntaxis on the present-

23 day stress field, the sedimentary basins of central, southern and offshore Thailand are

24 characterized by structural styles that are somewhat inconsistent with those predicted to result

25 from India-Eurasia collision. Furthermore, localized variations in $\mathrm{S}_{\mathrm{Hmax}}$ orientation, and the 
predominance of structures associated with purely extensional rifting, indicate that other processes also influence the stress field in Thailand. We suggest that stresses generated by the Sumatran-Andaman subduction zone may also have resulted in significant deformation in offshore Thailand and that the stress pattern may also be perturbed at very local (several $\mathrm{km}$ ) scales by mechanically weak faults.

Key words: Present-day Stress; Thailand; Borehole Breakout; Neotectonics.

\section{Introduction}

Thailand lies in the heart of one of the most tectonically active regions on Earth and displays an extensive history of Cenozoic deformation (Morley, 2002; Hall \& Morley, 2004). Consequently the present-day stress field provides insight into a region of continental crust that is actively deforming (Morley, 2001; Tingay et al., in press). Understanding present-day stress orientations is important for several reasons including: testing tectonic and fault evolution models for the region, hazard prediction associated with fault reactivation, and for the petroleum industry with regard to borehole stability and predicting the orientation of open fracture systems (Hall and Morley, 2004; Morley et al., 2004; Vigny et al., 2005; Tingay et al., 2009).

The Cenozoic tectonic evolution of Indochina is often considered to be controlled by stresses and strains arising from the ongoing collision of India with Eurasia (Molnar \& Tapponnier, 1975; Morley, 2002; England \& Molnar, 2005). The nature of Himalayan extrusion into SE Asia remains a topic of debate, with some authors proposing rigid block escape tectonics (Molnar \& Tapponnier, 1975; Tapponnier et al., 1982; Leloup et al. 2001; Replumaz and Tapponier 2003) whereas other authors suggest that deformations can be better matched by viscous or visco- 
51 extrusion, all models predict a fan-like present-day maximum horizontal stress $\left(\mathrm{S}_{\mathrm{Hmax}}\right)$ pattern in

52 Indochina centered on the eastern Himalayan syntaxis, with present-day $\mathrm{S}_{\mathrm{Hmax}}$ oriented NNW-

53 SSE to NNE-SSW throughout much of Indochina (Huchon et al., 1994; Kong \& Bird, 1997;

54 Morley, 2007). The modeled NNW-SSE to NNE-SSW S $\mathrm{H}_{\mathrm{Hmax}}$ orientation in Indochina is

55 supported by stress orientations estimated from earthquake focal mechanisms solutions in

56 northern Thailand and the Yunnan Region of China (Fig. 1; Holt et al., 1991; Huchon et al.,

57 1994; Morley et al., 2001; Morley, 2007). However, there is a relative absence of seismicity

58 south of approximately $17^{\circ} \mathrm{N}$ latitude in Indochina and thus it is not known whether the fan-

59 shaped stress pattern observed in regions adjacent to the Himalayan syntaxis extends into

60 southern Thailand and offshore Indochina.

61

62 Models of extrusion tectonics predict different distances at which forces generated at the

63 Himalayan syntaxis should influence the stress field in SE Asia (Molnar \& Tapponnier, 1975;

64 Morley, 2002; Hall \& Morley, 2004). For example, the rigid block escape tectonics model

65 predicts that the stress pattern, and associated deformations, throughout much of the Sunda plate

66 would be controlled by Himalayan extrusion (Molnar \& Tapponnier, 1975; Huchon et al., 1994).

67 However, the Cenozoic tectonic evolution of Indochina has also been strongly influenced by

68 processes other than Himalayan extrusion, most notably stresses arising from the Java-Sumatra-

69 Andaman subduction zone to the south and west of Thailand, gravitational collapse of thickened

70 continental crust in Indochina and the coupling between the Burma block in Myanmar with India

71 (Morley, 2001; Hall \& Morley, 2004; Morley et al., in press; Searle \& Morley, in press). Hence,

72 the primary aim of this study is to determine the present-day $\mathrm{S}_{\mathrm{Hmax}}$ orientation in central and

73 southern Thailand and the Gulf of Thailand (south of $17^{\circ} \mathrm{N}$ latitude) in order to better establish

74 the forces controlling the present-day stress field in Indochina and examine the distance at which

75 forces generated by the Himalayan syntaxis influence the stress pattern in SE Asia. 
77 Thailand displays some exceptional examples of extensional fault geometries that can be seen from satellite images, open cast coal mines and from 2D and 3D reflection seismic data (e.g. Rigo de Rhigi et al., 2002; Uttamo et al., 2003; Morley et al., 2004). These fault patterns commonly display multiple orientations, and complex fault propagation and linkage patterns that indicate inheritance of older fabrics, and complex evolution of the stress field with time (e.g. Morley and Wonganan, 2000; Kornsawan and Morley 2002; Morley et al., 2004; Morley et al., 2007). Investigation of the modern stress field can help determine whether fault orientations oblique to the main rift trend can be explained by simple reactivation of deeper structures, or whether other factors, such as localized stress rotations need to be considered. Hence, a secondary aim of this study is to examine the stress field at small-scales within sedimentary basins in order to investigate whether complex fault patterns in Thailand may be the result of local stress perturbations or the reactivation of deeper structures.

\section{Geological Summary}

Central and southern Thailand and the Gulf of Thailand are tectonically significant regions of Southeast Asia because they lie along the north-south transition from the orogenic region of the Himalayan syntaxis to the subduction-dominated Java-Sumatra margin further south. The tectonic development of Indochina is often considered to be dominated by widespread, largescale strike-slip faulting associated with Himalayan extrusion tectonics (Tapponier \& Molnar, 1975; Tapponnier et al., 1986). More recent work has, however, established that the Cenozoic tectonic evolution of Thailand is considerably more complex (Hall and Morley, 2004; Morley et al., in press; Searle \& Morley, in press). The geography of Thailand very strongly expresses

Cenozoic deformation that can be divided into seven main provinces, three in the south and four in the north (Morley et al., in press). The three southern provinces comprise Peninsular Thailand, 
101 the Gulf of Thailand and the Andaman Sea, whilst the northern provinces consist of the Western

102 Highlands, the central region, northern central region and the Khorat Plateau (Fig. 1). The

103 provinces are described below from south to north.

105 The Gulf of Thailand is dominated by Cenozoic rift systems, and has been an area of subsidence, 106 and extensive sedimentation since the Eocene (e.g. Lockhart et al., 1997; Jardine, 1997, Morley 107 and Westaway, 2006). Some basins are large, extremely deep and subsided rapidly, such as the 108 super-deep Pattani and Malay Basins, which in places contain over $7 \mathrm{~km}$ of Neogene section 109 (Morley \& Westaway, 2006). The present day shape of the gulf is due to a sea-level highstand 110 covering an extensive, broadly subsiding intra-continental post-rift basin (maximum water depth 111 of $80 \mathrm{~m}$ ), which extends onshore as the Central Basin.

113 The Andaman Sea is a region affected by Late Oligocene-Early Miocene transtension, followed 114 by Early Pliocene sea floor spreading in a pull-apart setting (Khan and Chakraborty, 2005).

115 Major N-S dextral strike-slip was initiated when western Myanmar became coupled to India and 116 was dragged northwards (along the Sagaing Fault) with respect to both Sumatra to the south, and 117 Peninsular Thailand to the east (see review in Curray, 2005). In contrast with the subdued Gulf of 118 Thailand bathymetry, the Andaman Sea is a large back-arc region with bathymetry related to the 119 Sumatra-Andaman plate boundary, strike-slip fault margins, and rifted passive-margins flanking 120 a deep marine back-arc spreading centre (maximum water depth 3,777 m).

122 Peninsular Thailand is a hilly strip of narrow highlands uplifted during the Cenozoic (particularly 123 the Late Oligocene to early Miocene; Upton, 1999). It is only a narrow strip of land due to late 124 Cenozoic tectonic processes driving subsidence in the Andaman Sea area to the west, and the 125 Gulf of Thailand to the east. The peninsula also contains a few small rift basins (e.g. Surat Thani 
126 Basin) and is cut by two major NE-SW trending Cenozoic dextral strike-slip faults (Khlong

127 Marui and Ranong faults; Fig. 1).

129 The central region, in which Bangkok is located, forms a broad flat plain (Central Plains) that 130 narrows northwards. The plains are $450 \mathrm{~km}$ long, up to $125 \mathrm{~km}$ wide and range in elevation from

131 sea level to $50 \mathrm{~m}$. The central region plains are a remarkable expression of an extensive, young,

132 post-rift (thermal subsidence) basin called the Chao Phraya Basin. This basin began to

133 unconformably cover the Late Oligocene-Miocene rift basins (Phitsanulok, Kampaeng Saeng and

134 Suphan Buri Basins) and intervening pre-Cenozoic rocks during the Late Miocene or early

135 Pliocene (Morley et al., 2007).

136

137 East of the Central Plains region is the Khorat Plateau, which is a low-topography area lying at

$138 \sim 500$ m elevation, underlain by $\sim 3000-4000 \mathrm{~m}$ thickness of predominately sub-horizontal

139 Mesozoic continental clastics of the Khorat Group (Kozar et al., 1992). The Khorat Group is

140 affected by variably trending Cenozoic folds that in some areas give rise to hilly topography,

141 most notably around the western margin of the Khorat Plateau and the Phu-Phan uplift (Fig. 1).

142 Apatite fission track dating of the Khorat Group in the more strongly folded areas indicates

143 exhumation linked with rising folds occurred between about $50 \mathrm{Ma}$ and $30 \mathrm{Ma}$ (Upton, 1999).

145 West of the Central Plains region is the Shan Plateau, an uplifted region straddling eastern

146 Myanmar and Western Thailand composed predominantly of Palaeozoic sedimentary and

147 metasedimentary rocks extensively intruded by Mesozoic and early Cenozoic granites. The

148 western highlands in Thailand mark the eastern limit of the Plateau. Typical maximum elevations

149 in the Plateau area are $\sim 1500 \mathrm{~m}$. The western extent of the Plateau is sharply defined by the Shan

150 Scarp and the adjacent N-S striking Sagaing Fault (Fig. 1). The Sagaing Fault is one of the 
151 largest and most active strike-slip faults in the world, with dextral motion in the order of $\sim 2.0$ $\mathrm{cm} / \mathrm{yr}$ (Vigny et al., 2003). That motion accommodates about two thirds of the northwards motion of India relative to Indochina. On satellite images the plateau is spectacularly cross-cut by a network of predominantly N-S and NW-SE trending major Cenozoic strike-slip faults that are clearly visible as linear topographic features (e.g. Le Dain et al,. 1984, Lacassin et al., 1997, Lacassin et al., 1998, Morley, 2004). The NW-SE striking Mae Ping and Three Pagodas Fault zones are the best developed of these strike-slip fault zones in Thailand. During the Paleogene they underwent major ( $>100 \mathrm{~km}$ ), sinistral motion, while minor (up to a few tens of kilometers) dextral displacement occurred during the Late Oligocene and Neogene (Lacassin et al., 1997; Morley, 2004).

The Cenozoic rift trend passes from the central plains region into northern Thailand, however extensional activity continued into more recent times in the north where some faults remain active today (Bott et al., 1997, Fenton et al., 1997, Fenton et al., 2003). The northern rifts are characterized by over forty intermontane rift basins forming isolated plains (Fig. 1) that lie at elevations between $200 \mathrm{~m}$ and $500 \mathrm{~m}$. These basins retain their syn-rift topography, with the intermontane plains flanked by high hills with elevations up to $1500 \mathrm{~m}$, composed predominantly of Palaeozoic-Early Mesozoic rocks (Morley et al., in press).

The Cenozoic rift basins of central, western, northern and offshore Thailand are highly variable in size, with many being only $10 \mathrm{~s}-100 \mathrm{sm}^{2}$ in size and $10 \mathrm{~s}$ to $100 \mathrm{~s}$ of meters deep. The N-S orientation of these basins has been suggested to indicate that they are purely the result of Himalayan extrusion, with the basins forming as pull aparts due to displacement along major NW-SE trending faults (Tapponnier et al., 1986; Polachan et al., 1991). Some basins in western and northern Thailand do appear to have a strike-slip or oblique extension origin, but basins 
176 further to the south and east grade into extensional basins where a purely strike-slip origin can be 177 disproved (Morley, 2001; Morley, 2007). Furthermore, Cenozoic strike-slip deformation has 178 arisen from both deformation at the eastern Himalayan syntaxis (Huchon et al., 1994; Kong \& 179 Bird, 1997) and from coupling of the Indian Plate with the Burma block that introduced a N-S 180 trending broad dextral shear couple on western Thailand and eastern Burma from the Oligocene 181 onwards (e.g. Curray, 2005). Other forces that potentially acted on Thailand during the Cenozoic are from the Sumatran-Andaman subduction zone and buoyancy forces associated with thickening of the continental crust during the Late Cretaceous and Paleogene (Morley, 2001; Hall and Morley, 2004; Morley et al., in press; Tingay et al., in press).

That the Cenozoic tectonic evolution of Thailand has been influenced by a complex interplay of different forces, and is not purely a consequence of India-Eurasia collision, is suggested by both the spatial variations in deformation style described above and the evolution of structures over time. Oligocene-Miocene rift basins are developed over folds, thrusts and strike-slip faults formed during the Paleogene (Morley, 2007; Morley et al., 2007; Morley et al., in press). Pullapart basins in western Thailand that developed during the Late Oligocene-Early Miocene are associated with a change from sinistral to dextral strike-slip motion along major NW-SE to N-S trending faults (Morley, 2004). The pull-apart basins appear to have ceased activity during the

194 Middle Miocene, while extensional basins to the east continued to be active (Lacassin et al., 195 1997; Morley, 2007). Several Miocene-Pliocene stress changes can be inferred in the rift basins, 196 both as variations in dominant fault orientation over time and by alternating phases of inversion 197 and extension (Lacassin et al., 1997; Morley, 2007; Morley et al., 2007; Morley et al., in press). 198 Most significantly for the modern stress regime is that a final phase of widespread basin 199 inversion occurred around the Miocene-Pliocene boundary, after which time extension stopped or 200 was greatly reduced in most onshore rift basins (Morley et al., 2001). 


\section{Determination of Present-Day Maximum Horizontal Stress Orientation}

203 The present-day stress tensor in sedimentary basins is conventionally simplified to consist of four 204 components: the vertical stress magnitude, $S_{H \max }$ magnitude, minimum horizontal stress 205 magnitude and $\mathrm{S}_{\mathrm{Hmax}}$ orientation (Bell, 1996). The vertical, maximum and minimum horizontal 206 stresses are typically assumed to be principal stresses, particularly in sedimentary basins that 207 generally have little topographic variation (Bell, 1996). Herein, we focus primarily on 208 determining the $S_{\mathrm{Hmax}}$ orientation, which is assumed to represent a principal stress. Present-day $209 S_{\mathrm{Hmax}}$ orientations in Thailand's basins were determined from borehole breakouts and drilling210 induced fractures (DIFs) interpreted from four-arm caliper and resistivity image log data. When a

211 borehole is drilled, the material removed from the subsurface is no longer supporting the 212 surrounding rock. As a result, the stresses become concentrated in the surrounding rock (i.e. the 213 wellbore wall; Kirsch, 1898). Borehole breakouts are stress-induced elongations of the wellbore 214 and occur when the wellbore stress concentration exceeds that required to cause compressive 215 failure of intact rock (Bell \& Gough, 1979). The elongation of the cross-sectional shape of the 216 wellbore is the result of compressive shear failure on intersecting conjugate planes, which causes 217 pieces of the borehole wall to spall off (Bell \& Gough, 1979). The maximum circumferential 218 stress around a vertical borehole occurs perpendicular to the maximum horizontal stress (Kirsch, 219 1898). Hence, borehole breakouts are elongated perpendicular to the maximum horizontal stress 220 direction (Bell \& Gough, 1979).

222 Drilling-induced fractures are caused by tensile failure of the borehole wall and form when the 223 wellbore stress concentration is less than the tensile strength of the rock (Aadnøy, 1990). The 224 minimum circumferential stress around a vertical borehole occurs in the direction of the 
maximum horizontal stress (Kirsch, 1898). Hence, DIFs are oriented in the $\mathrm{S}_{\mathrm{Hmax}}$ direction

226 (Aadnøy \& Bell, 1998).

Breakouts are interpreted herein from the Schlumberger High-Resolution Dipmeter Tool (HDT) and Oil-Based Dipmeter Tool (OBDT) logs and resistivity image logs. The HDT and OBDT are four-arm caliper tools with two pairs of caliper arms at $90^{\circ}$ to each other. Each arm has a pad on the end containing one or two resistivity 'buttons'. The resistivity data from four-arm caliper tools are processed to obtain information about the formation (primarily dip and strike of

233 bedding) and to calculate hole volume (Schlumberger, 1986). However, borehole breakouts can

234 be interpreted from unprocessed HDT log data. The logs used to interpret breakouts from the 235 HDT are the:

236 borehole deviation (DEVI) and azimuth (HAZI);

- $\quad$ azimuth of pad one (P1AZ);

- bearing of pad one relative to the high side of the hole (RB), and;

- diameter of the borehole in two orthogonal directions ('caliper one' (C1) given by arms one and three and 'caliper two' (C2) from arms two and four).

242 The tool tends to rotate as it is pulled up the borehole due to the lay of the cable (cable torque).

243 However, the tool stops rotating where the cross-sectional shape of the borehole is elongated 244 when one caliper pair becomes 'stuck' in the elongation direction (Fig. 2; Plumb \& Hickman, 245 1985). The combined use of the six logs listed above allows the interpreter to identify zones of 246 borehole breakout and the orientation of the elongation (Fig. 2). Many non-circular wellbore 247 cross-sectional shapes are not stress-induced, such as washout and key-seating (Plumb \& 248 Hickman, 1985). Borehole breakout is distinguished from other borehole elongations on HDT $249 \operatorname{logs}$ using a strict set of criteria presented in Table 1 (Plumb \& Hickman, 1985). 
251 Resistivity image logs evolved from the four-arm dipmeter logs. There are a number of resistivity

252 buttons on each pad of the resistivity image tool, for example 16 buttons per pad on

253 Schlumberger's Formation Micro Scanner (FMS). The multiple resistivity buttons provide an

254 image of the borehole wall based on resistivity contrasts (Fig. 2; Ekstrom et al., 1987).

255 Resistivity image tools also measure the hole size and logs obtained by the HDT. Several types 256 of resistivity image tools are available. However, only Schlumberger's FMS and Formation 257 Micro Imager (FMI) were used in this study. The FMI tool is an improved version of the FMS 258 tool that has 24 resistivity buttons on each pad and a flap attached to each pad with a further 24 259 buttons, thereby giving greater coverage of the wellbore wall.

261 The resistivity image of the wellbore wall allows for a more reliable interpretation of breakouts 262 than can be made by using dipmeter data alone (Heidbach et al., in press). Drilling-induced 263 fractures can also be recognised on image logs (DIFs cannot be interpreted on four-arm caliper 264 logs). Breakouts appear on resistivity image logs as broad, parallel, often poorly resolved 265 conductive zones separated by $180^{\circ}$ and exhibiting caliper enlargement in the direction of the 266 conductive zones. DIFs appear on image logs as narrow, well defined, conductive fractures (Fig. 267 2; Tingay et al., 2008).

269 Breakouts and DIFs can rotate in inclined boreholes and do not always directly yield the 270 horizontal stress orientation (Mastin 1988; Peska \& Zoback 1995). However, the current state of 271 stress in Thailand is believed to be a normal or strike-slip faulting stress regime (Meyer, 2003; 272 Morley, 2004). Breakouts and DIFs do not show any significant rotation in orientation and still 273 yield the approximate $\mathrm{S}_{\mathrm{Hmax}}$ orientation in boreholes with less than $20^{\circ}$ deviation in a normal or 
strike-slip faulting stress regime (Peska \& Zoback 1995). Hence, breakouts and DIFs were only used to estimate the $S_{H \max }$ direction in wellbore intervals with deviations of less than $20^{\circ}$.

The mean $\mathrm{S}_{\mathrm{Hmax}}$ orientation from each well was given a quality ranking according to the World

Stress Map Project criteria with A-quality being the highest $\left(S_{H \max }\right.$ reliable to within $\left.\pm 15^{\circ}\right)$ and Equality the lowest (no reliable orientation determinable; Heidbach et al., in press). Table 2 lists the quality ranking criteria for breakouts and DIFs interpreted from image and four-arm caliper 281 logs.

\section{Present-Day Maximum Horizontal Stress Orientation in Thailand Basins}

We analyzed four-arm caliper and resistivity image logs for borehole breakout and DIFs in 106 wells from sedimentary basins covering $1000 \mathrm{~km} \mathrm{N-S}$ extent through central, southern and offshore Thailand. A total of 124.6 kilometers of four-arm caliper logs and image logs were examined in six onshore and offshore basins, including 6019 meters of image log data from nine wells (Table 3). Borehole breakouts and/or DIFs were observed in 76 wells (Fig. 3; Table 3; data for individual wells freely available from the World Stress Map Project). A total of 558 breakouts and 45 DIFs with a combined length of 12085 meters were interpreted across the six regions (Figs. 3 and 4; Table 3). Image and four-arm caliper logs were also examined in 30 wells that either did not contain breakouts/DIFs or were deviated by $>20^{\circ}$ and thus were not used herein

293 (ranked E-quality; Table 3). The observed breakouts and DIFs indicate that $\mathrm{S}_{\mathrm{Hmax}}$ is, as regional averages, oriented N-S to NNW-SSE in all six basins with standard deviations of between $23-45^{\circ}$ (Fig. 4; Table 3). Tingay et al. (in press) undertook statistical analysis of the stress orientations within each basin using the Rayleigh Test to confirm the confidence level at which the null

297 hypothesis of stress orientations being random within a province can be rejected (Coblentz \& 298 Richardson, 1992). The null hypothesis can be rejected in all six basins at a confidence level of at 
least $97.5 \%$, indicating that the average stress orientations for each basin can be reliably used as

300 regional stress orientations (Tingay et al., in press). However, it is important to note that there is

301 a significant amount of localized stress variation in several basins, the origins of which are

302 discussed below. Furthermore, aside from some examples discussed below, borehole breakouts

303 and DIFs observed within individual wells generally show fairly consistent orientations with

304 depth.

\section{Discussion}

Implications of the Regional Stress Pattern for Deformation Resulting from India-Eurasia

308 Collision

309 The majority of previously published present-day stress orientations for Thailand and Indochina

310 have been derived from earthquake focal mechanism solutions that indicate a curvilinear fan-

311 shaped stress pattern emanating from the eastern Himalayan syntaxis, with NNW-SSE to NNE-

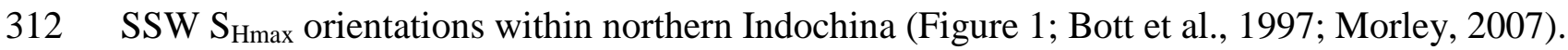

313 Hence, the N-S average $\mathrm{S}_{\mathrm{Hmax}}$ orientations observed in the onshore Phitsanulok, Khorat and

314 Suphan Buri Basins are consistent with the stress orientations observed from earthquake focal

315 mechanisms solutions in northern Thailand (Figs. 1, 3 and 4; Morley, 2007; Tingay et al., in

316 press). Present-day average $\mathrm{S}_{\mathrm{Hmax}}$ orientations for basins in the Gulf of Thailand are also broadly

317 consistent with the onshore stress field, ranging from N-S in the Pattani Basin to NW-SE to

318 NNW-SSE in the Chumphon and North Malay Basins (Table 3; Figs. 4 and 5; Meyer, 2003).

319 Hence, the present-day stress orientations obtained for basins in Thailand indicate that the fan-

320 shaped stress field emanating from the eastern Himalayan syntaxis may, at least in the region

321 studied herein, extend down into the Gulf of Thailand. 
323 That forces from the eastern Himalayan syntaxis extend down to central and southern Thailand is

324 also supported by geomorphology and trenching data, which suggest segments of major strike

325 slip faults in western central and peninsular Thailand, particularly the Mae Ping, Three Pagodas,

326 Ranong, Klong Marui faults, have been active through the Quaternary, with dextral motion on

327 the NW-SE striking faults and sinistral motion on the NE-SW striking faults (Fenton et al.,

328 2003). Furthermore, a $M_{b} 5.6$ earthquake occurred on the Ranong fault in 1978 and three GPS

329 stations in southern Thailand, between the Ranong and Khlong Mauri faults, record 2-4 mm per

330 year NNE motions relative to stable Sundaland, indicating current movement along these faults

331 (Fig. 3; Shrestha, 1987; Simons et al., 2007).

333 The results of the stress analysis herein, coupled with the palaeostress data, is in stark contrast

334 with interpretations from seismicity and GPS data that suggest forces exerted by the eastern

335 Himalayan syntaxis may only extend as far as northern Thailand. The number and magnitude of

336 recorded earthquakes in Thailand decreases southwards and large, natural earthquakes are very

337 rare south of $17^{\circ} \mathrm{N}$ latitude. Indeed, the onshore earthquakes shown to the south of $17^{\circ} \mathrm{N}$ latitude

338 in Figure 1 are thought to be the result of water loading in dams (Bott et al. 1997). The

339 seismogenic front in Thailand approximates the southern limit of the intermontane rift basins in

340 Northern Thailand, whereas rift basins south of this limit lie beneath a broad, flat plain that is the

341 early stage of post-rift (thermal) subsidence. Hence, the reduction in seismicity from north to

342 south could, on the basis of seismicity distribution alone, be interpreted to represent the outer

343 limit of eastern Himalayan syntaxis forces being transmitted through the crust. This hypothesis is

344 further supported by the results of GPS analysis in Indochina that reveals a significant difference

345 in modern displacement between Thailand and the Yunnan region of China (Simons et al., 2007;

346 Morley, 2007). Yunnan is experiencing SSW to WSW motions relative to Sundaland (including

347 Thailand) that are associated with clockwise rotation of blocks immediately south of the eastern 
348 Himalayan syntaxis (Simons et al., 2007). Block motion diminishes from about 12-13 mm/yr

$349 \mathrm{SSW}$ in the east of Yunnan, to $\sim 6 \mathrm{~mm} / \mathrm{yr}$ WSW in the west of Yunnan, while displacements in

350 northern Thailand are $\sim 2-3 \mathrm{~mm} / \mathrm{yr}$ to the ENE (Simons et al., 2007). Hence, the GPS data also

351 suggest that forces associated with the eastern Himalayan syntaxis may currently have

352 insufficient magnitude to cause measurable strain south of northern Thailand (England and

353 Molnar, 2005). Indeed, this GPS data and distribution of seismicity has even been used to suggest

354 that a plate boundary between Sunda and Eurasia occurs along the seismogenic front (Bird,

355 2003). However, despite the distribution of seismicity and GPS analysis, the present-day regional

$356 \mathrm{~N}-\mathrm{S} \mathrm{S}_{\mathrm{Hmax}}$ orientations determined herein suggest that stresses related to the eastern Himalayan

357 syntaxis are currently transmitted approximately $1000 \mathrm{~km}$ beyond the limit of seismicity in

358 northern Thailand.

360 It is also interesting to note that the average stress orientations are well constrained in the

361 Phitsanulok, Khorat, Suphan Buri and Chumphon Basins, all of which exhibit standard

362 deviations in breakout/DIF orientations of $23-26^{\circ}$ (Fig. 4). The $\mathrm{S}_{\mathrm{Hmax}}$ orientations indicated by

363 breakouts in the Pattani Basin also indicate an N-S average orientation, but with a higher

364 standard deviation ( $40^{\circ}$; Fig. 4). However, the orientation of the 38 breakouts observed within the

365 North Malay Basin are highly variable; occurring in almost all azimuths, and thus the present-day

366 regional stress orientation in the North Malay Basin is only poorly constrained (Fig. 4).

367 Furthermore, there is significant variation in the average stress orientations from individual wells,

368 particularly in the Pattani and North Malay Basins, suggesting that horizontal stress magnitudes

369 may be more isotropic in these southernmost Thai basins (Fig. 5). Hence, it is possible that the

370 Pattani and North Malay Basin region marks a key transition zone from N-S $\mathrm{S}_{\mathrm{Hmax}}$ orientations in

371 onshore Thailand and the northern Gulf of Thailand (primarily controlled by forces generated at 
the eastern Himalayan syntaxis) into the predominantly NW-SE to NNW-SSE S $_{\text {Hmax }}$ orientations observed in the Malay Basin (Fig. 3; Tjia \& Ismail, 1994; Tingay et al., in press).

\section{Present-day Stress and the Origin of Deformation in the Gulf of Thailand}

The present-day geomorphology, structural style of sedimentary basins, earthquake activity and stress regime all suggest that forces related to the eastern Himalayan syntaxis, and associated $\mathrm{S}_{\mathrm{Hmax}}$ magnitude in Thailand, diminishes southwards. The present-day stress regime in the Yunnan region of China is one of significant strike-slip activity, but $\mathrm{S}_{\mathrm{Hmax}}$ magnitude diminishes southwards with northern Thailand being less tectonically and seismically active with the

381 predominant deformation mode being episodic mixed normal and strike-slip faulting, while central and southern Thailand are tectonically quiescent. Analysis of petrophysical log, drilling tests and conditions of wellbore failure in the Pattani Basin indicates a present-day normal/strike$\operatorname{slip}\left(S_{\mathrm{Hmax}} \approx \mathrm{S}_{\mathrm{v}}>S_{\mathrm{hmin}}\right)$ to strike-slip $\left(\mathrm{S}_{\mathrm{Hmax}}>\mathrm{S}_{\mathrm{v}}>\mathrm{S}_{\mathrm{hmin}}\right)$ faulting stress regime (Meyer, 2003). However, the estimated $\mathrm{S}_{\mathrm{Hmax}}$ gradients of $20-22.5 \mathrm{MPa} / \mathrm{km}$ in the Pattani Basin are well below the frictional limit to sliding and thus are unlikely to generate seismicity (Meyer, 2003).

The present-day stress, structural style, seismicity and geomorphological data discussed above is superficially consistent with the low level of present-day tectonic activity in the Gulf of Thailand and which would be expected of a post-rift basin. There is, however, an anomalous feature: the

391 presence of hundreds, if not thousands, of low displacement ( 20m-300m) young normal faults clearly visible on 2D and 3D seismic reflection data in the post-rift section of the Pattani and

393 North Malay Basins (Rigo de Rhigi et al., 2002; Morley et al., 2004; Fig. 6). These faults tend to 394 form extensive, 3-8 km wide curvilinear graben trends composed of conjugate convergent faults, 395 large enough to have trapped recoverable reserves of gas in the order of 27 trillion cubic feet (e.g. 396 Kornsawan and Morley 2002; Rigo de Rhigi et al. 2002, Morley et al. 2004). The post-rift fault 
style is completely different from the underlying syn-rift section, which shows the typical rift style of half grabens with dominant boundary faults that display several kilometers of displacement.

401 Such well-developed normal faults are very unusual in a post-rift basin. The faults appear to have 402 developed episodically during the Neogene, and some faults cut up to the sea floor. Hence this 403 particular mode of (probably aseismic) deformation is very recent and possibly continuing today

404 (Morley et al., 2004). The development of these faults is problematic since earthquake and 405 borehole data indicate stress magnitudes are insufficient for failure and 10 years of GPS data 406 indicate no differential motion across the Gulf of Thailand. However, one possible answer to this 407 problem may lie in the episodic plate boundary effects at the Sumatra-Andaman subduction zone. 408 The $M_{\mathrm{w}} 9.1,26^{\text {th }}$ December 2004, Sumatran-Andaman earthquake produced considerable differential movement of the crust on the western and eastern side of the Gulf of Thailand (Vigny et al., 2005). GPS data showed that Phuket (western side of the gulf) underwent $272 \mathrm{~mm}$ WSW

411 co-seismic displacement relative to the Indian Plate, followed by $27 \mathrm{~mm}$ of post-seismic motion 412 in the following five days, while the eastern Khorat area (onshore eastern Thailand) underwent $41337 \mathrm{~mm}$ WSW co-seismic motion (Vigny et al., 2005). If the recurrence interval of such an 414 earthquake is approximately 500 years, and assuming $26 \mathrm{~cm}$ of differential strain across the Gulf 415 for each event, this equates to $\sim 10.5 \mathrm{~km}$ extension over a 20 my period. Such a value is sufficient 416 to explain the amount of Miocene-Recent post-rift extension in the Gulf of Thailand.

418 Two moderate earthquakes $\left(M_{\mathrm{w}}=4.7\right.$ on $27 / 09 / 2006$ and $M_{\mathrm{w}}=5.0$ on $\left.7 / 10 / 2006\right)$ occurred in 419 close temporal and spatial proximity in the NW Gulf of Thailand in 2006. In records going back 420 to 1976, the Global CMT catalog (www.globalcmt.org) does not record any other earthquakes in 421 the Gulf of Thailand. We suggest that these earthquakes may be a delayed response to the 2004 
Sumatran-Andaman earthquake. The earthquakes have a pure dip-slip normal faulting moment tensor solution and suggest a N-S $\mathrm{S}_{\mathrm{Hmax}}$ orientation similar to nearby borehole breakout data.

The Sumatran-Andaman mega-thrust earthquake illustrates the potential for factors other than the eastern Himalayan syntaxis to affect deformation in Thailand. There are several large faults in the Andaman Sea (offshore continuations of the Ranong Fault and Mergui Faults) that were most active during Oligocene-early Miocene rifting, but extend to near the sea floor, indicating continued recent reactivation. The modern stress orientations are not optimally oriented for sinistral reactivation of the Ranong Fault, but the episodic perturbation of the regional stress field by mega-earthquakes, that is super-imposed upon the N-S regional stress pattern radiating from the eastern Himalayan syntaxis, may explain the observed fault activity.

\section{Post-rift Fault Patterns in Thailand and Localized Stress Rotations}

435 The post-rift fault zones of the Pattani and North Malay Basins provide superb examples of fault 436 linkage geometries (Figs. 5 and 6; Rigo de Rhigi et al., 2002; Morley et al., 2004). This post-rift 437 fault pattern is particularly striking in the North Malay Basin (Fig. 6e), where short N-S striking 438 fault segments curve to join long NW-SE trending faults, as schematically illustrated in Figure 7. 439 These long NW-SE striking faults are characterized by extremely high length (L) to displacement 440 (D) ratios (up to 300:1, compared to typical 10-20:1 ratios ( $\mathrm{D}=10^{-1} \mathrm{~L}$ to $\mathrm{D}=20^{-1} \mathrm{~L}$ ) worldwide) 441 and tend to align along underlying syn-rift faults to form a long fault with multiple displacement 442 highs and lows along strike, suggesting that these faults have formed by the linkage of previously 443 isolated faults (Dawers et al., 1993; Walsh and Watterson, 1988; Morley et al., 2004). Indeed, 444 some of these long low-displacement faults are 40-80 km long and may be composed of 20-30 445 linked faults that were initially $1-4 \mathrm{~km}$ long and typically each have maximum throws of only 446 100-300 m (Leo, 1997, Morley et al., 2004). Morley et al. (2004) inferred that the short N-S 
447 faults in the North Malay Basin formed sub-parallel to the post-rift $S_{\mathrm{Hmax}}$ direction, while the long

448 NW-SE faults formed by reactivation and linkage along the existing syn-rift faults. Morley et al.

449 (2004) suggested that the reactivation of the non-optimally oriented NW-SE syn-rift faults in a

$450 \mathrm{~N}-\mathrm{S} \mathrm{S}_{\mathrm{Hmax}}$ extensional stress regime indicated that the syn-rift faults have low cohesion or

451 coefficient of friction.

453 The predominantly N-S present-day $\mathrm{S}_{\mathrm{Hmax}}$ orientations determined in this study support the 454 inferred N-S post-rift $\mathrm{S}_{\mathrm{Hmax}}$ direction predicted by Morley et al. (2004) from fault patterns in the 455 North Malay and Pattani Basins. However, breakouts in one well, drilled close to a large NW-SE 456 trending syn-rift fault in the North Malay Basin, indicate a N-S $\mathrm{S}_{\mathrm{Hmax}}$ direction at shallow depth 457 that rotates to a WNW-ESE direction deeper, near the large NW-SE fault (Fig. 7). The 458 observation that $S_{\mathrm{Hmax}}$ in this well rotates parallel to the strike of nearby syn-rift faults suggests 459 that the post-rift reactivation of syn-rift faults may not be because they are zones of low cohesion 460 or coefficient of friction, but instead because localized stress rotations in the vicinity of these 461 faults renders them favorably oriented to be reactivated.

463 Present-day localized stress perturbations are also observed in the Pattani Basin. The average $464 \mathrm{~S}_{\mathrm{Hmax}}$ orientations for individual wells in the Pattani Basin are predominantly N-S (generally 465 between NNE-SSW and NNW-SSE; Fig. 5b). However, $\mathrm{S}_{\mathrm{Hmax}}$ orientations along the Platong466 Pladang trend range from NNW-SSE to NE-SW and appear to be locally deflected to remain sub467 parallel to the strike of post-rift extensional faults (Fig. 5b). Furthermore, approximately east468 west $\mathrm{S}_{\mathrm{Hmax}}$ orientations are observed in four wells near the Erawan Field at the southern end of 469 the Pattani Basin, though breakouts in these four wells are elongated parallel to structure and thus may be an artifact resulting from the relatively common misinterpretation of enlarged drilling- 
471 induced or natural fractures as breakouts on caliper log data (Fig. 5; Dart \& Zoback, 1989;

472 Meyer, 2003).

474 Localized stress rotations are also observed in the Phitsanulok Basin, onshore Thailand. A total 475 of 54 breakouts and 12 DIFs were observed in 12 wells in the Phitsanulok Basin and indicate a 476 reasonably well constrained $\mathrm{N}-\mathrm{S}$ average $\mathrm{S}_{\mathrm{Hmax}}$ orientation $\left(005^{\circ} \mathrm{N} \pm 25^{\circ}\right.$; Table 3$)$. However, the stress orientations determined for individual wells reveals that the stress field appears to be locally variable within the Phitsanulok Basin (Fig. 8). Borehole breakouts indicate an approximately N-S $\left( \pm 20^{\circ}\right) \mathrm{S}_{\mathrm{Hmax}}$ orientation in eight wells examined in the Phitsanulok Basin. However, borehole breakouts in three wells suggest local stress orientations ranging from NNE-

481 SSW to almost E-W (Fig. 8). Furthermore, 12 DIFs were observed in fractured Mesozoic quartzites in the basement within Well X that range in orientation from NNE-SSW to NE-SW, indicating a NNE SSW average $\mathrm{S}_{\mathrm{Hmax}}$ orientation $\left(034^{\circ} \mathrm{N} \pm 9^{\circ}\right.$; Fig. 8$)$.

The occurrence of small-scale stress perturbations, such as those observed in the Malay, Pattani and Phitsanulok Basins, is often considered to indicate that horizontal stress magnitudes are relatively isotropic and/or detached from primary sources of stress (Sonder, 1990; Bell, 1996; Tingay et al., 2005; Heidbach et al., 2007). However, the inference of isotropic horizontal stress magnitudes due to the presence of small-scale stress perturbations is inconsistent with the large

490 number of breakouts and DIFs observed in this study, the recent structural styles in the region 491 and with stress magnitudes estimated from wellbore failure (Meyer, 2003; Morley et al., in press). Meyer (2003) used leak-off test data and modeling of borehole breakout occurrence to

493 estimate that a normal/strike-slip $\left(S_{\mathrm{Hmax}} \approx S_{\mathrm{v}}>S_{\mathrm{hmin}}\right)$ to strike-slip $\left(S_{\mathrm{Hmax}}>S_{\mathrm{v}}>S_{\mathrm{hmin}}\right)$ faulting stress

494 regime is most likely present in the Pattani Basin. Furthermore, the majority of stress regimes 495 inferred from earthquake focal mechanism solutions in onshore Thailand also suggest the 
dominance of a present-day strike-slip faulting stress regime (Fig. 1). Therefore, it is unlikely that the localized stress field variations observed in the Phitsanulok, Pattani and North Malay Basins are due to isotropic horizontal stress magnitudes, nor are there any geological units in the region that are likely to act as mechanical detachment layers. However, the fault-parallel stress orientations observed in the Platong-Pladang trend and in parts of the Phitsanulok and North

501 Malay Basins, suggest that the regional N-S $\mathrm{S}_{\mathrm{Hmax}}$ stress orientation is being locally deflected by existing structures. Structures that are associated with mechanical contrasts, such as salt and shale diapirs, igneous intrusions and faults can locally perturb the stress field, with the $S_{\mathrm{Hmax}}$ orientation typically thought to be deflected perpendicular to mechanically stiff structures and parallel to weak structures (Yale, 1994; Bell, 1996; Tingay et al., 2006). Hence, the localized rotation in the stress field observed in the Pattani, North Malay and Phitsanulok Basins are interpreted to primarily result from the presence of mechanically weak faults.

The variable stress orientations observed in the Phitsanulok, Pattani and North Malay Basins also

510 have important implications for hydrocarbon production. For example, Well X in northern central

511 Thailand was drilled to estimate the potential for oil production from fractured pre-Cenozoic 512 basement rocks under the Phitsanulok Basin. Well Z, which penetrated the fractured Mesozoic 513 basement less than 1000 meters north of Well X, produced about 1 million barrels of oil (Fig. 9).

514 However, subsequent wells (X, Y, W; Fig. 9) drilled to try and capitalize on this basement

515 production were largely unsuccessful or had only minor production before watering out.

516 Understanding the modern stress field distribution is important for determining why only one 517 well was successful in this field. Rocks commonly contain many fractures, most of which are 518 closed or cemented. Fractures tend to open and hydraulically conductive either as a response to 519 the modern stress field (i.e. open fractures lie at a low angle to the maximum horizontal stress 520 direction or are close to shear failure), or because they are propped open by being partially 
521 mineralized (Jones and Hillis, 2003). Figure 9 shows that wells X and Y intersected

522 predominantly NE-SW trending open fracture sets, while the successful basement producing well

523 (Z) intersected predominantly NNW-SSE trending fractures. The local $\mathrm{S}_{\mathrm{Hmax}}$ orientation in wells

$524 \mathrm{~V}$ and $\mathrm{X}$ is NE-SW to ENE-WSW; very different from the overall N-S trend in the Sirikit Field

525 of the Phitsanulok Basin (Fig. 9). The orientation of open fractures in wells $\mathrm{X}$ and $\mathrm{Y}$ is what

526 would be predicted from these local stress orientations. There is no borehole breakout data from

527 well $\mathrm{Z}$, but the fracture orientations from core suggest that the $\mathrm{S}_{\mathrm{H} \max }$ orientation in the vicinity of

528 well Z has rotated to lie sub-parallel to the adjacent NNW-SSE normal fault, similar to that

529 observed elsewhere in the Sirikit field (Figs. 8 and 9). The different local $S_{\text {Hmax }}$ orientations and

530 basement fracture orientations between non-producing and producing wells suggest that the

531 NNW-SSE fractures are better connected to oil-bearing reservoir rocks, while the NE-SW to

532 ENE-WSW trends are connected to (deeper) water-bearing strata.

\section{Conclusions/Summary}

535 The present-day $S_{\mathrm{Hmax}}$ orientations, combined with the detailed analysis of recent structural

536 styles, provide new insight into both the large-scale and small-scale tectonic evolution of

537 Thailand. This study undertakes the first detailed analysis of present-day stress orientation in

538 sedimentary basins in onshore and offshore Thailand, revealing that a predominately N-S

539 regional $\mathrm{S}_{\mathrm{Hmax}}$ orientation exists throughout central and southern Thailand and the Gulf of

540 Thailand. The regional N-S $\mathrm{S}_{\mathrm{Hmax}}$ orientation is broadly consistent with stress orientations

541 estimated from earthquake focal mechanism solutions in Northern Thailand and are interpreted to

542 predominately reflect stresses generated by the eastern Himalayan syntaxis (Huchon et al., 1994).

543 Hence, the N-S $S_{H \max }$ regional orientation and normal-strike-slip $\left(\mathrm{S}_{\mathrm{Hmax}} \approx \mathrm{S}_{\mathrm{v}}>\mathrm{S}_{\mathrm{hmin}}\right)$ to strike-slip

544 faulting stress regime $\left(S_{\mathrm{Hmax}}>\mathrm{S}_{\mathrm{v}}>\mathrm{S}_{\mathrm{hmin}}\right)$ observed in Thai basins is also likely to be primarily

545 controlled by forces generated at the eastern Himalayan syntaxis. The relative absence of natural 
seismicity south of northern Thailand has been previously suggested to indicate the outer limit of

547 influence of the eastern Himalayan syntaxis on the stress pattern in SE Asia. However, the stress

548 orientations observed from borehole breakouts and DIFs indicates that the eastern Himalayan

549 syntaxis has a major control on the stress field up to $1000 \mathrm{~km}$ south of the seismically active

550 zone.

552 Stress orientations observed from breakouts and DIFs in Thailand become more scattered in the southernmost Pattani and North Malay Basins, suggesting that this region may mark the transition zone in which forces other than those generated at the eastern Himalayan syntaxis become more significant. Furthermore, a well defined extensional post-rift fault pattern is observed in the Pattani and North Malay Basin that is in contrast with the strike-slip faulting stress regime predicted from stresses generated by the eastern Himalayan syntaxis. One possible other source of stress and cause of post-rift deformation in the Pattani and North Malay Basin is the Sumatran-Andaman subduction zone, with major earthquakes along this subduction zone known to have caused significant co-seismic and post-seismic displacements in central and

561 southern Thailand (Vigny et al., 2005). Thus, we hypothesize that stresses generated along this arc may also have influenced stresses in Thailand and possibly account for the over $10 \mathrm{~km}$ of

563 Miocene-Recent post-rift extension.

565 The post-rift sequences of Thailand offer excellent examples of present-day localized stress 566 rotations adjacent to existing structures, with $\mathrm{S}_{\mathrm{Hmax}}$ orientations often observed to be oriented 567 sub-parallel to the strike of nearby faults. We suggest the rotation of $S_{\mathrm{Hmax}}$ to be sub-parallel to 568 structure indicates that the faults are mechanically weak. Furthermore, the localized rotation of 569 the stress field near major structures may offer an explanation for the development of long low570 displacement post-rift faults striking sub-parallel to syn-rift structures in the North Malay and 
571 Pattani Basins. The observation that these NW-SE striking faults are inconsistent with the N-S

$572 \mathrm{~S}_{\mathrm{Hmax}}$ orientation predicted during post-rift times has been previously suggested to indicate that

573 the syn-rift faults have low cohesion and coefficient of friction or that the region has undergone

574 an additional phase of deformation in which a NW-SE $S_{\mathrm{Hmax}}$ orientation existed (Morley et al.,

575 2004). However, we suggest that mechanically weak syn-rift faults may have generated small-

576 scale stress perturbations that locally resulted in a stress orientation that is more favorable for the 577 reactivation of syn-rift faults that propagated into the post-rift sequences.

\section{Acknowledgments}

580 The authors wish to thank PTT Exploration and Production and Chevron Thailand for permission

581 to publish these results. This manuscript has benefited greatly from the detailed and constructive 582 reviews provided by Chris Elders and Thomas Maurin. This research has been funded by the 583 Australian Research Council.

References

586 Aadnøy, B.S., 1990. Inversion technique to determine the in-situ stress field from fracturing data. Journal of Petroleum Science and Engineering 4, 127-141.

588 Aadnøy, B.S., Bell, J.S., 1998. Classification of drill-induce fractures and their relationship to in$589 \quad$ situ stress directions. The Log Analyst 39, 27-42.

590 Bell, J.S., Gough, D.I., 1979. Northeast-southwest compressive stress in Alberta: Evidence from 591 oil wells. Earth and Planetary Science Letters 45, 475-482.

592 Bell, J.S., 1996. Petro Geoscience 1. In situ stresses in sedimentary rocks (part 2): applications of stress measurements. Geoscience Canada 23, 135-153. 
Binh, N.T.T., Tokunaga, T., Son, H.P., Binh, M.V., 2007. Present-day stress and pore pressure fields in the Cuu Long and Nam Con Son Basins, offshore Vietnam. Marine and Petroleum

Bird, P., 2003. An updated digital model of plate boundaries. Geochemistry, Geophysics, Geosystems 4, 1027, doi:10.1029/2001GC000252.

Bott, J., Wong, I., Prachuab, S., Wechbunthung, B., Hinthong, C., Surapirome, S., 1997. Contemporary seismicity in northern Thailand and its tectonic implications. In: The International Conference on Stratigraphy and Tectonic Evolution of Southeast Asia and the South Pacific, Bangkok, Thailand, pp. 453-464.

Coblentz, D., Richardson, R.M., 1995. Statistical trends in the intraplate stress field. Journal of Geophysical Research 100, 20245-20255.

Curray, J.R., 2005. Tectonics and history of the Andaman Sea region. Journal of Asian Earth Sciences 25, 187-232.

Dart, R.L., Zoback, M.L., 1989. Wellbore Breakout Analysis within the Central and Eastern Continental United States. The Log Analyst 30, 12-25.

Dawers, N.H., Anders, M.H., Scholz, C.H., 1993. Fault length and displacement: scaling laws.

611 Ekstrom, M.P., Dahan, C.A., Chen, M.Y., Lloyd, P.M., Rossi, D.J., 1987. Formation imaging 612 with microelectrical scanning arrays. The Log Analyst 28, 294-306.

613 England, P.C., Molnar, P., 2005. Late Quaternary to decadal velocity fields in Asia. Journal of 614 Geophysical Research 110 (B12), doi:10.1029/2004JB003541.

615 Fenton, C.H., Charusiri, P., Hinthong, C., Lumjuan, A., Mangkonkarn, B., 1997. Late quaternary 616 faulting in northern Thailand. In: International Conference on Stratigraphy and Tectonic 617 Evolution of South East Asia and the South Pacific. Bangkok, Thailand, pp. 436-452. 
618 Fenton, C.H., Charusiri, P., Wood, S.H., 2003. Recent paleoseismic investigations in Northern

619 Thailand. Annals of Geophysics 46, 957-981.

620 Hall, R., Morley, C.K., 2004. Sundaland Basins. In: Continent-Ocean Interactions within the East 621 Asian Marginal Seas. Clift, P. Wang, P., Kuhnt, W. and Hayes, D.E. (Eds.) AGU 622 Geophysical Monograph 149, 55-85.

623 Heidbach, O., Reinecker, J., Tingay, M., Müller, B., Sperner, B., Fuchs, K., Wenzel, F., 2007. 624 Plate boundary forces are not enough: Second- and third-order stress patterns highlighted in 625 the World Stress Map database. Tectonics 26, TC6014, doi:10.1029/2007TC002133.

626 Heidbach, O., Tingay, M., Barth, A., Reinecker, J., Kurfeß, D., Müller, B., in press. Global 627 crustal stress pattern based on the World Stress Map database release 2008. Tectonophysics, 628

629 Holt, W.E., Ni, J.F., Wallace, T.C., Haines, A.J., 1991. The active tectonics of the eastern 630 Himalayan syntaxis and surrounding regions. Journal of Geophysical Research 96 (B9), $631 \quad 14595-14632$.

632 Huchon, P., Le Pichon, X., Rangin, C., 1994. Indo-China Peninsular and the collision of India 633 and Eurasia. Geology 22, 27-30.

634 Jardine, E., 1997. Dual petroleum systems governing the prolific Pattani basin, offshore 635 Thailand. Petroleum systems of S.E. Asia and Australasia Conference, Jakarta, May 21-23, $636 \quad 1997,351-363$.

637 Jones, R. M., Hillis, R.R., 2003. An integrated, quantitative approach to assessing fault-seal risk. 638 American Association of Petroleum Geologists Bulletin 87, 189-215.

639 Khan, P.K., Chakraborty, P.P., 2005. Two-phase opening of Andaman Sea: a new seismotectonic 640 insight. Earth and Planetary Science Letters 229, 259-271.

641 Kirsch, V., 1898. Die Theorie der Elastizität und die Beddürfnisse der Festigkeitslehre.

642 Zeitschrift des Vereines Deutscher Ingenieure 29, 797-807. 
643 Kong, X., Bird, P., 1997. Neotectonics of Asia: thin-shell finite-element models with faults. In:

644 Yin, A. and Harrison, T.M. (Eds.), The Tectonic Evolution of Asia. Cambridge University

645 Press, New York, pp. 18-34.

646 Kornsawan, A., Morley, C.K., 2002. The origin and evolution of complex transfer zones (graben 647 shifts) in conjugate fault systems around the Funan Field, Pattani basin, Gulf of Thailand.

$648 \quad$ Journal of Structural Geology 24, 435-449.

649 Kozar, M.G., Crandall, G.F., Hall, S.E., 1992. Integrated structural and stratigraphic study of the

650 Khorat Basin, Rat Buri Limestone (Permian), Thailand. In: Piancharoen, C. (ed.),

651 Proceedings of National Conference on Geological Resources of Thailand, Potential for

652 Future Development, Department of Mineral Resources, Bangkok, Thailand, 682-736.

653 Lacassin, R., Hinthong, C., Siribhakdi, K., Chauviroj, S., Charoenravat, A., Maluski, H., Leloup,

654 P.H., Tapponnier, P., 1997. Cenozoic diachronic extrusion and deformation of western

655 Indochina: structure and 40Ar/39Ar evidence from NW Thailand. Journal of Geophysical

$656 \quad$ Research 102 (B5), 10013-10037.

657 Lacassin, R., Replumaz, A., Leloup, P.H., 1998. Hairpin river loops and slip-sense inversion on 658 Southeast Asian strike-slip faults. Geology 26, 703-706.

659 Le Dain, A.Y., Tapponnier, P., Molnar, P., 1984. Active faulting and tectonics of Burma and 660 surrounding regions. Journal of Geophysical Research, 89 B1, 453-472.

661 Leloup, P.H., Arnaud, N., Lacassin, R., Kienast, J.R., Harrison, T.M., Trong, T.T.P., Replumaz, 662 A., Tapponnier, P., 2001. New constraints on the structure, thermochronology and timing of 663 the Ailao ShaneRed River shear zone, SE Asia. Journal of Geophysical Research 106, 6683$664 \quad 6732$.

665 Leo, C.T.A., 1997. Exploration in the Gulf of Thailand in deltaic reservoirs, related to the 666 Bongkot Field. In: Fraser, A.J., Matthews, S.J., Murphy, R.W. (Eds.), Petroleum Geology of 667 Southeast Asia. Geological Society of London, Special Publication 126, 77-87. 
668 Lockhart, B.E., Chinoroje, O., Enomoto, C.B., Hollomon, G.A., 1997. Early Tertiary deposition

669 in the southern Pattani Trough, Gulf of Thailand. The International Conference on

670 Stratigraphy and Tectonic Evolution of Southeast Asia and the South Pacific, Bangkok,

671 Thailand, 476-489.

672 Mastin, L., 1988. Effect of borehole deviation on breakout orientations. Journal of Geophysical $673 \quad$ Research 93, 9187-9195.

674 Meyer, J.J., 2003. The determination and application of in situ stresses in petroleum exploration 675 and production. Unpublished Ph.D. Thesis, University of Adelaide, Adelaide, 237 pp.

676 Shrestha, P.M., 1987. Investigation of Active Faults in Kanchanaburi Province, Thailand.

677 Unpublished M. Sc. Thesis, Asian Institute of Technology, Bangkok, 106 pp.

678 Molnar, P., Tapponnier, P., 1975. Cenozoic tectonics of Asia: effects of a continental collision. $679 \quad$ Science 189, 419-426.

680 Morley, C.K., 2001. Combined escape tectonics and subduction rollback-backarc extension: a 681 model for the Tertiary rift basins in Thailand, Malaysia and Laos. Journal of the Geological $682 \quad$ Society of London 158, 461-474.

683 Morley, C.K., 2002. A tectonic model for the Tertiary evolution of strike-slip faults and rift 684 basins in SE Asia. Tectonophysics 347, 189-215.

685 Morley, C.K., 2004. Nested strike-slip duplexes, and other evidence for Late Cretaceous686 Paleogene transpressional tectonics before and during India-Eurasia collision, in Thailand, 687 Myanmar and Malaysia. Journal of the Geological Society of London 161, 799-812.

688 Morley, C.K., 2007. Variations in Late Tertiary-Recent strike-slip and oblique extensional 689 geometries within Indochina: the influence of pre-existing fabrics. Journal of Structural $690 \quad$ Geology 29, 36-58. 
691 Morley, C.K., Wonganan, N., 2000. Normal fault displacement characteristics, with particular reference to synthetic transfer zones, Mae Moh Mine, Northern Thailand. Basin Research 12, $1-22$.

694

Morley, C.K., Woganan, N., Sankumarn, N., Hoon, T.B., Alief, A., Simmons, M., 2001. Late Oligocene-Recent stress evolution in rift basins of Northern and Central Thailand: implications for escape tectonics. Tectonophysics 334, 115-150.

Morley, C.K., Haranya, C., Phoosongsee, W., Pongwapee, S., Kornasawan, A., Wonganan, N., 2004. Activation of rift oblique and rift parallel pre-existing fabrics during extension and their effect on deformation style: Examples from the rifts of Thailand. Journal of Structural Geology 26, 1803-1829.

Morley, C. K., Westaway, R., 2006. Subsidence in the super-deep Pattani and Malay basins of Southeast Asia: a coupled model incorporating lower-crustal flow in response to post-rift sediment loading. Basin Research 18, 51-84.

Morley, C.K., Gabdi, S., Seusutthiya, K., 2007. Fault superimposition and linkage resulting from stress changes during rifting: Examples from 3D seismic data, Phitsanulok Basin, Thailand. Journal of Structural Geology 29, 646-663.

Morley, C.K., Charusiri, P., Watkinson, I.M., Searle, M., in press. Structural geology of Thailand during the Cenozoic. In: Ridd, M., Barber A. (Eds.), The Geology of Thailand. Geological Society of London Memoir.

Peska, P., Zoback, M.D., 1995. Compressive and tensile failure of inclined wellbores and determination of in situ stress and rock strength. Journal of Geophysical Research 100, $12791-12811$.

Pivnik, D.A., Nahm, J., Tucker, R.S., Smith, G.O., Nyein, K., Nyunt, M., Maung P.H., 1998. Polyphase deformation in a fore-arc/back-arc basin, Salin subbasin, Myanmar (Burma). American Association of Petroleum Geologists Bulletin 82, 1837-1856. 
Plumb, R.A., Hickman, S.H., 1985. Stress-induced borehole elongation: A comparison between the Four-Arm Dipmeter and the Borehole Televiewer in the Auburn Geothermal Well. Journal of Geophysical Research 90, 5513-5521.

Polachan, S., Pradidtan, S., Tongtaow, C., Janmaha, S., Intarawijitr, K., Sangsuwan, C., 1991. Development of Cenozoic basins in Thailand. Marine and Petroleum Geology 8, 84-97.

Replumaz, A., Tapponnier, P., 2003. Reconstruction of the deformed collision zone between India and Asia by backward motion of lithospheric blocks. Journal of Geophysical Research 108, doi:10.1029/2001JB00066.

Rigo De Rhigi, L., Baranowski, J., Chaikiturajai, C., Nelson, G., Wechsler, D., Mattingly, G., 2002. Block B8/32, Gulf of Thailand Petroleum System and Implementation of Technology in Field Development. Seapex Press 6, 46-55.

Schlumberger, 1986. Dipmeter Interpretation. New York, USA, Schlumberger Limited, 76 p.

Searle, M.P., Morley, C.K., in press. Tectonics and thermal evolution of Thailand in the regional context of South-East Asia. In: Ridd, M., Barber A. (Eds.), The Geology of Thailand. Geological Society of London Memoir.

Shen, Z.-K., Lu, J., Wang, M., Burgmann, R., 2005. Contemporary crustal deformation around the southeast borderland of the Tibetan Plateau. Journal of Geophysical Research 110 (B11409), doi: 10.1029/2004JB003421.

Shrestha, P.M., 1987. Investigation of Active Faults in Kanchanaburi Province, Thailand. Unpublished M. Sc. Thesis, Asian Institute of Technology, Bangkok, 106 pp.

Simons, W.J.F., Socquet, A., Vigny, C., Ambrosius, B.A.C., Abu, S.H., Promthong, C., Subarya, Sarsito, D.A., Matheussen, S., Morgan, P., Spakman, W., 2007. A decade of GPS in Southeast Asia: resolving Sundaland motion and boundaries. Journal of Geophysical Research 112, B06420. doi:10.1029/2005JB003868. 
Sonder, L.J., 1990. Effects of density contrasts on the orientation of stresses in the lithosphere: relation to principal stress direction in the Transverse Ranges, California. Tectonics 9(4), 761-771.

Tapponnier, P., Peltzer, G., Le Dain, A.Y., Armijo, R., Cobbold, P., 1982. Propagating extrusion tectonics in Asia: new insights from simple experiments with plasticine. Geology 10, 611616.

Tapponnier, P., Peltzer, G., Armijo, R., 1986. On the mechanism of collision between India and Asia. In: Coward, M.P., Ries, A.C. (Eds.), Collision Tectonics. Geological Society of London Special Publication 19, 115-157.

Tingay, M., Müller, B., Reinecker, J., Heidbach, O., Wenzel, F., Fleckenstein, P., 2005. Understanding tectonic stress in the oil patch: The World Stress Map Project. The Leading Edge 24, 1276-1282.

Tingay, M., Müller, B., Reinecker, J., Heidbach, O., 2006. State and origin of the present-day stress field in sedimentary basins: New results from the World Stress Map Project. Golden Rocks, American Rock Mechanics Association 2006 Conference, Paper 06-1049.

Tingay, M., Reinecker, J., Müller, B., 2008. Borehole breakout and drilling-induced fracture analysis from image logs. World Stress Map Project Stress Analysis Guidelines (available online at www.world-stress-map.org).

Tingay, M., Hillis, R., Morley, C., King, R., Swarbrick, R., Damit, A., 2009. Present-day stress and neotectonics of Brunei: implications for petroleum exploration and production. AAPG

761 Tingay, M., Morley, C., King, R., Hillis, R., Coblentz, D., Hall, R., in press. Present-day stress field of Southeast Asia. Tectonophysics, doi:10.1016/j.tecto.2009.06.019.

763 Tjia, H.D., Ismail, M.I, 1994. Tectonic implications of well-bore breakouts in Malaysian basins. Geological Society of Malaysia Bulletin 36, 175-186. 
765 Upton, D., Bristow, C., Hurford, A.J., Carter, A., 1997. Cenozoic tectonic denudation in 766 northwestern Thailand: Provisional results from apatite fission-track analysis. In: The 767 International Conference on Stratigraphy and Tectonic Evolution of Southeast Asia and the $768 \quad$ South Pacific, Bangkok, Thailand, pp. 421-431.

769 Uttamo, W., Elders, C.F., Nicols, G.J., 2003. Relationships between Cenozoic strike-slip faulting 770 and basin opening in northern Thailand. In: Storti, F., Holdsworth, R.E., Salvini, F. (Eds.), 771 Intraplate strike-slip deformation belts. Geological Society of London, Special Publication $772 \quad 210,89-108$.

773 Vigny, C., Simons, W.J.F., Abu, S., Bamphenyu, R., Satirapod, C., Choosakul, N., Subarya, C., 774 Socquet, A., Omar, K., Abdin, H.Z., Ambrosius, A.A.C., 2005. Insight into the 2004 775 SumatraneAndaman earthquake from GPS measurements in southeast Asia. Nature 436, 201776206.

777 Walsh, J.J., Watterson, J., 1988. Analysis of the relationship between displacements and 778 dimensions of faults. Journal of Structural Geology 10, 239-247.

779 Yale, D.P., 2003. Fault and stress magnitude controls on variations in the orientation of in situ 780 stress. In: Ameen M.S. (Ed.), Fracture and in-situ stress characterization of hydrocarbon 781 reservoirs. Geological Society of London Special Publication 209, pp. 55-64. 
784 Tables

785 Table 1: Criteria for recognizing breakouts on four-arm caliper (HDT-type) logs (Plumb \&

786 Hickman, 1985).

1. Tool rotation must cease in the zone of elongation (maximum of $15^{\circ}$ rotation within breakout).

2. There must be clear tool rotation into and out of the elongation zone (at least $30^{\circ}$ ).

3. The difference between caliper extensions must be $>6 \mathrm{~mm}$.

4. The smaller of the caliper readings must be very close to bit size ( $\pm 5 \%$ tolerance).

5. The length of the elongation zone must be $>1 \mathrm{~m}$

6. The elongation orientation should not coincide with the high side of the borehole in wells deviated by more than $5^{\circ}\left( \pm 5^{\circ}\right.$ tolerance $)$.

Table 2: World Stress Map (WSM) project quality ranking criteria for breakouts and drilling-

789 induced fractures (DIFs) interpreted from four-arm caliper and image logs (Heidbach et al., in

790 press). SD: standard deviation of breakout/DIF orientations.

\begin{tabular}{|c|c|c|c|c|c|}
\hline Data Type & A-quality & B-quality & C-quality & D-quality & E-quality \\
\hline $\begin{array}{l}\text { Breakouts } \\
\text { (four-arm } \\
\text { caliper logs) }\end{array}$ & $\begin{array}{l}\geq 10 \text { breakouts } \\
\text { with combined } \\
\text { length } \geq 300 \mathrm{~m} \\
\text { and } \mathrm{SD} \leq 12^{\circ} \text { in } \\
\text { a single well }\end{array}$ & $\begin{array}{l}\geq 6 \text { breakouts } \\
\text { with combined } \\
\text { length } \geq 100 \mathrm{~m} \\
\text { and } \mathrm{SD} \leq 20^{\circ} \text { in } \\
\text { a single well }\end{array}$ & $\begin{array}{l}\geq 4 \text { breakouts } \\
\text { with combined } \\
\text { length } \geq 30 \mathrm{~m} \\
\text { and } \mathrm{SD} \leq 25^{\circ} \text { in } \\
\text { a single well }\end{array}$ & $\begin{array}{l}<4 \text { breakouts or } \\
\text { combined } \\
\text { length }<30 \mathrm{~m} \\
\text { and } \mathrm{SD} \leq 40^{\circ}\end{array}$ & $\begin{array}{l}\text { No breakouts } \\
\text { observed or } \\
\text { breakouts with } \\
\text { SD }>40^{\circ}\end{array}$ \\
\hline $\begin{array}{l}\text { Breakouts } \\
\text { (image logs) }\end{array}$ & $\begin{array}{l}\geq 10 \text { breakouts } \\
\text { with combined } \\
\text { length } \geq 100 \mathrm{~m} \\
\text { and } \mathrm{SD} \leq 12^{\circ} \text { in } \\
\text { a single well }\end{array}$ & $\begin{array}{l}\geq 6 \text { breakouts } \\
\text { with combined } \\
\text { length } \geq 40 \mathrm{~m} \\
\text { and } \mathrm{SD} \leq 20^{\circ} \text { in } \\
\text { a single well }\end{array}$ & $\begin{array}{l}\geq 4 \text { breakouts } \\
\text { with combined } \\
\text { length } \geq 20 \mathrm{~m} \\
\text { and } \mathrm{SD} \leq 25^{\circ} \text { in } \\
\text { a single well }\end{array}$ & $\begin{array}{l}<4 \text { breakouts or } \\
\text { combined } \\
\text { length }<20 \mathrm{~m} \\
\text { and } \mathrm{SD} \leq 40^{\circ}\end{array}$ & $\begin{array}{l}\text { No breakouts } \\
\text { observed or } \\
\text { breakouts with } \\
\text { SD }>40^{\circ}\end{array}$ \\
\hline $\begin{array}{c}\text { DIF (image } \\
\text { logs) }\end{array}$ & $\begin{array}{l}\geq 10 \text { DIFs with } \\
\text { combined } \\
\text { length } \geq 100 \mathrm{~m} \\
\text { and } \mathrm{SD} \leq 12^{\circ} \text { in } \\
\text { a single well }\end{array}$ & $\begin{array}{l}\geq 6 \text { DIFs with } \\
\text { combined } \\
\text { length } \geq 40 \mathrm{~m} \\
\text { and } \mathrm{SD} \leq 20^{\circ} \text { in } \\
\text { a single well }\end{array}$ & $\begin{array}{l}\geq 4 \text { DIFs with } \\
\text { combined } \\
\text { length } \geq 20 \mathrm{~m} \\
\text { and } \mathrm{SD} \leq 25^{\circ} \text { in } \\
\text { a single well }\end{array}$ & $\begin{array}{c}<4 \text { DIFs or } \\
\text { combined } \\
\text { length }<20 \mathrm{~m} \\
\text { and } \mathrm{SD} \leq 40^{\circ}\end{array}$ & $\begin{array}{c}\text { No DIFs } \\
\text { observed or } \\
\text { DIFs with SD } \\
>40^{\circ}\end{array}$ \\
\hline
\end{tabular}


794 Table 3: Summary of data analyzed and stress orientation results in Thailand basins. Wells:

795 number of wells for which image or caliper log data was examined; BO: number of breakouts

796 observed; DIF: number of drilling-induced fractures (DIF) observed, A-E: number of A-E quality

797 stress indicators; BO/DIF Length: total length of breakouts and DIF observed; BO/DIF Ave

$798 \mathrm{~S}_{\mathrm{Hmax}}$ and SD: unweighted average maximum horizontal stress orientation (and standard

799 deviation) from all individual breakouts and DIFs; Indicator Ave $\mathrm{S}_{\mathrm{Hmax}}$ and SD: quality weighted

800 average maximum horizontal stress orientation (and standard deviation) from stress indicators.

\begin{tabular}{|c|c|c|c|c|c|c|c|c|c|c|c|c|c|c|}
\hline \multirow[b]{2}{*}{ Basin } & \multirow[b]{2}{*}{ Wells } & \multirow[b]{2}{*}{ BO } & \multirow[b]{2}{*}{ DIF } & \multirow[b]{2}{*}{$\mathbf{A}$} & \multirow[b]{2}{*}{ B } & \multirow[b]{2}{*}{$\mathbf{C}$} & \multirow[b]{2}{*}{ D } & \multirow[b]{2}{*}{$\mathbf{E}$} & \multirow{2}{*}{$\begin{array}{c}\text { Log } \\
\text { Length } \\
(\mathbf{k m}) \\
\end{array}$} & \multirow{2}{*}{$\begin{array}{c}\text { BO/DIF } \\
\text { Length } \\
(\mathrm{m})\end{array}$} & \multicolumn{2}{|c|}{ BO/DIF } & \multicolumn{2}{|c|}{ Indicator } \\
\hline & & & & & & & & & & & $\begin{array}{c}\text { Ave } \\
S_{\mathrm{Hmax}} \\
\end{array}$ & SD & $\begin{array}{c}\text { Ave } \\
\mathbf{S}_{\text {Hmax }} \\
\end{array}$ & SD \\
\hline Phitsanulok & 26 & 54 & 12 & 3 & 1 & 1 & 7 & 14 & 13.5 & 1270 & $005^{\circ}$ & $25^{\circ}$ & $012^{\circ}$ & $23^{\circ}$ \\
\hline Khorat & 11 & 130 & 12 & 3 & 1 & 4 & 3 & 1 & 11.6 & 1504 & $000^{\circ}$ & $26^{\circ}$ & $173^{\circ}$ & $24^{\circ}$ \\
\hline Suphan Buri & 9 & 15 & 0 & 0 & 0 & 2 & 3 & 4 & 9.8 & 292 & $001^{\circ}$ & $23^{\circ}$ & $000^{\circ}$ & $16^{\circ}$ \\
\hline Chumphon & 7 & 24 & 21 & 0 & 1 & 3 & 3 & 1 & 8.0 & 167 & $161^{\circ}$ & $23^{\circ}$ & $159^{\circ}$ & $17^{\circ}$ \\
\hline Pattani & 42 & 297 & 0 & 0 & 8 & 7 & 23 & 4 & 70.2 & 8470 & $000^{\circ}$ & $40^{\circ}$ & $001^{\circ}$ & $25^{\circ}$ \\
\hline North Malay & 11 & 38 & 0 & 0 & 1 & 3 & 1 & 6 & 11.5 & 382 & $153^{\circ}$ & $45^{\circ}$ & $159^{\circ}$ & $33^{\circ}$ \\
\hline
\end{tabular}

801

802 


\section{Figure Captions}

804 Figure 1: The main Cenozoic-Recent tectonic and structural features of the Myanmar-Western 805 Thailand region of the back-arc mobile belt. Complied from Pivnik et al. (1998), Morley (2004) 806 and Curray (2005).

808 Figure 2: Examples of borehole breakout and drilling-induced fractures (DIFs) in Thailand 809 basins. (a) Borehole breakouts interpreted from four-arm caliper log data in the Pattani Basin.

810 Borehole breakouts are oriented approximately $095^{\circ} \mathrm{N}$, indicating a $005^{\circ} \mathrm{N}$ present-day maximum

811 horizontal stress $\left(\mathrm{S}_{\mathrm{Hmax}}\right)$ orientation. (b) DIFs observed on Formation Micro Scanner resistivity 812 image log data in the Chumphon Basin. DIFs are oriented approximately $155^{\circ} \mathrm{N}$, indicating a $813155^{\circ} \mathrm{N}$ present-day $\mathrm{S}_{\mathrm{Hmax}}$ orientation.

815 Figure 3: Present-day stress orientations, major structures and GPS-derived motions (relative to 816 a stable Sunda plate) in onshore and offshore Thailand, Vietnam and Malaysia. There is 817 significant scatter in stress directions between individual wells. However, the present-day stress 818 throughout Thailand is typically oriented N-S at a basin-scale. Stress orientations from offshore 819 Malaysia and Vietnam from Tjia \& Ismail (1994) and Binh et al., (2007). Relative motions 820 adapted from Simons et al., (2007).

822 Figure 4: Distribution of breakout (BOs) and drilling-induced fracture (DIFs) orientations in 823 Thailand basins. The maximum horizontal stress is oriented perpendicular to breakouts and 824 parallel to drilling-induced fractures. Ave $\mathrm{S}_{\mathrm{Hmax}}$ Azi: average maximum horizontal stress 825 orientation from all breakouts and DIFs; S.D: standard deviation of maximum horizontal stress 826 orientations; L: combined total length of breakouts and DIFs. 
828 Figure 5: Present-day maximum horizontal stress orientations in the Chumphon, North Malay 829 and Pattani Basins, Gulf of Thailand. Stresses are locally scattered, though are typically trend 830 between NNE-SSW and NNW-SSE and are oriented approximately N-S at the basin-scale (b)

831 Stress orientations in the Platong-Pladang trend in the Pattani Basin. Present-day maximum

832 horizontal stress orientations appear to be rotated sub-parallel to neighboring extensional faults 833 and to jogs in the half graben structure.

835 Figure 6: Illustration of syn-rift and post-rift fault patterns in the eastern Gulf of Thailand. a) 836 Regional syn-rift fault map of the Pattani and Khmer Basins based on 2D and 3D seismic 837 reflection data, illustrating fault patterns in the Late Oligocene-Early Miocene syn-rift section 838 compiled from unpublished maps made by Unocal (published in Morley et al. 2004), and 839 Lockhart et al. (1997). b) Detail of post-rift fault swarm patterns from the Northern Pattani basin 840 (redrawn from Rigo de Rhigi et al., 2002). c) The post-rift faults tend to form curvi-linear trends 841 of convergent conjugate faults with 10's meters to a few hundred meters displacement. These 842 trends often appear to be guided by underlying syn-rift faults which localize long, low843 displacement post rift faults, as illustrated for the Tantawan graben. d) Time structure map for the 844 Tantawan graben (redrawn from Rigo de Rhigi et al. 2002), absolute scale not shown (darker 845 colors $=$ deeper time-depths). Many of the post-rift faults tend to have different strikes from the 846 underlying syn-rift faults but join or splay off trends controlled by the syn-rift faults. e) Example 847 of fault map view geometry in the post-rift section from the North Malay basin (Morley et al. 848 2004). In d) and e) the black faults dip E to NE, while the light colored faults dip to the W to SW.

$850 \quad$ Figure 7: Schematic block diagram illustrating the interaction between post-rift and syn-rift 851 faults, and how $S_{H \max }$ orientation can be related to fault orientation. The rotation in $S_{H \max }$ 
852 direction with depth to be sub-parallel to syn-rift faults is illustrated from a well in the North 853 Malay Basin.

855 Figure 8: Present-day stress orientations in the Sirikit Field in the Phitsanulok Basin. Present-day 856 maximum horizontal stress orientations are predominately oriented N-S. However, stress 857 orientations often appear to be locally rotated sub-parallel to neighboring extensional faults and 858 drilling-induced fractures observed in Well $\mathrm{X}$ indicate a NE-SW stress orientation in the 859 basement.

861 Figure 9: Time-structure map for the base syn-rift horizon in part of the Sirikit Field (see Fig. 9 862 for location). The map also shows well trajectories, pre-rift fracture orientations intersected in 863 wells $\mathrm{X}, \mathrm{Y}$ and $\mathrm{Z}$, and $\mathrm{S}_{\mathrm{Hmax}}$ orientation for the field. Well $\mathrm{Z}$ produced 1 million barrels of oil 864 from NNW-SSE striking, open fractures in the Mesozoic quartzite basement. However, ENE865 WSW oriented open fractures in wells X and Y did not produce significant volumes of 866 hydrocarbons. We suggest that NNW-SSE striking basement fractures are more suitably oriented 867 for tapping overlying hydrocarbon reservoirs in the regional N-S $\mathrm{S}_{\mathrm{Hmax}}$ direction. 
Figure 1

Click here to download high resolution image

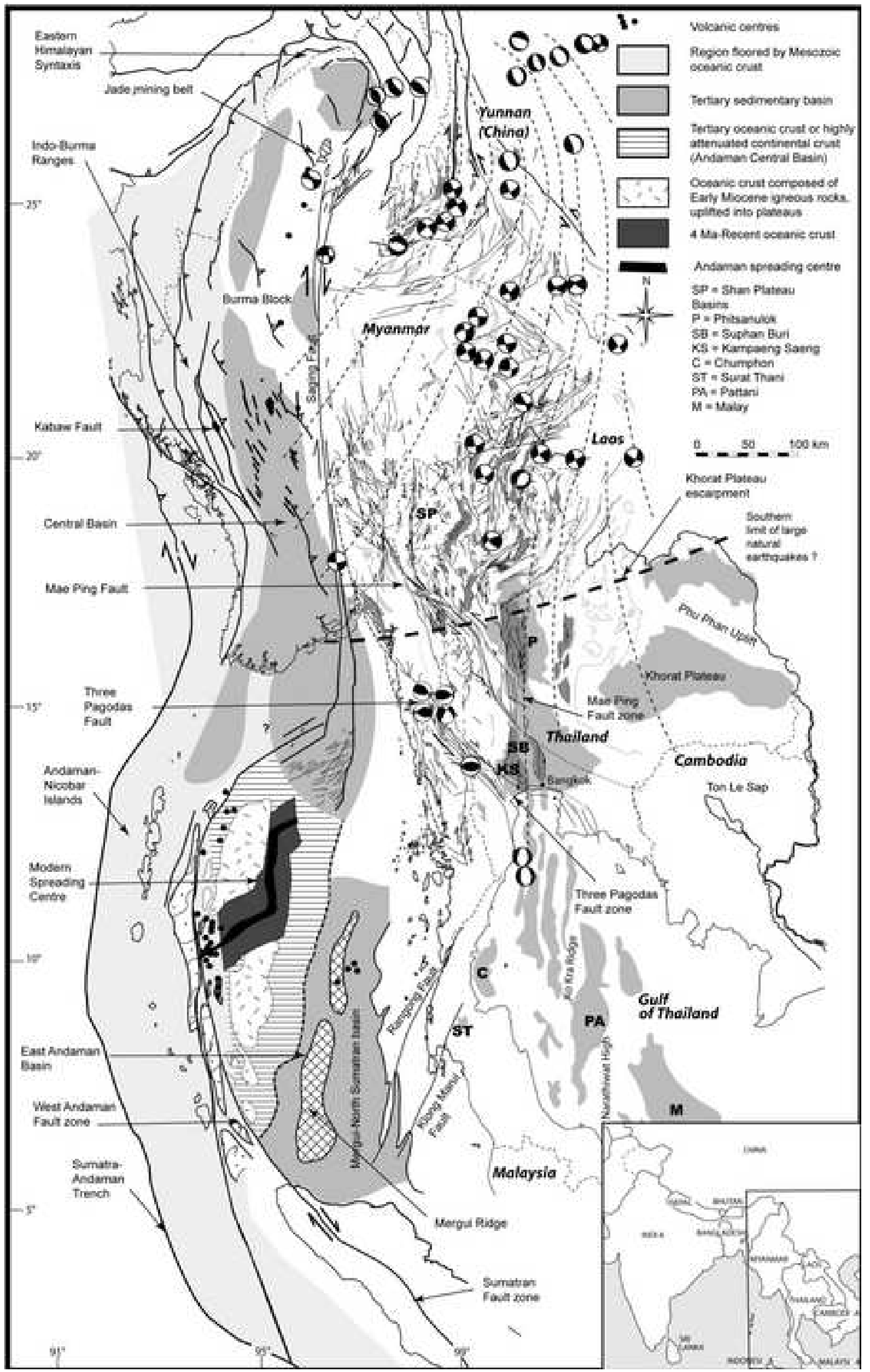



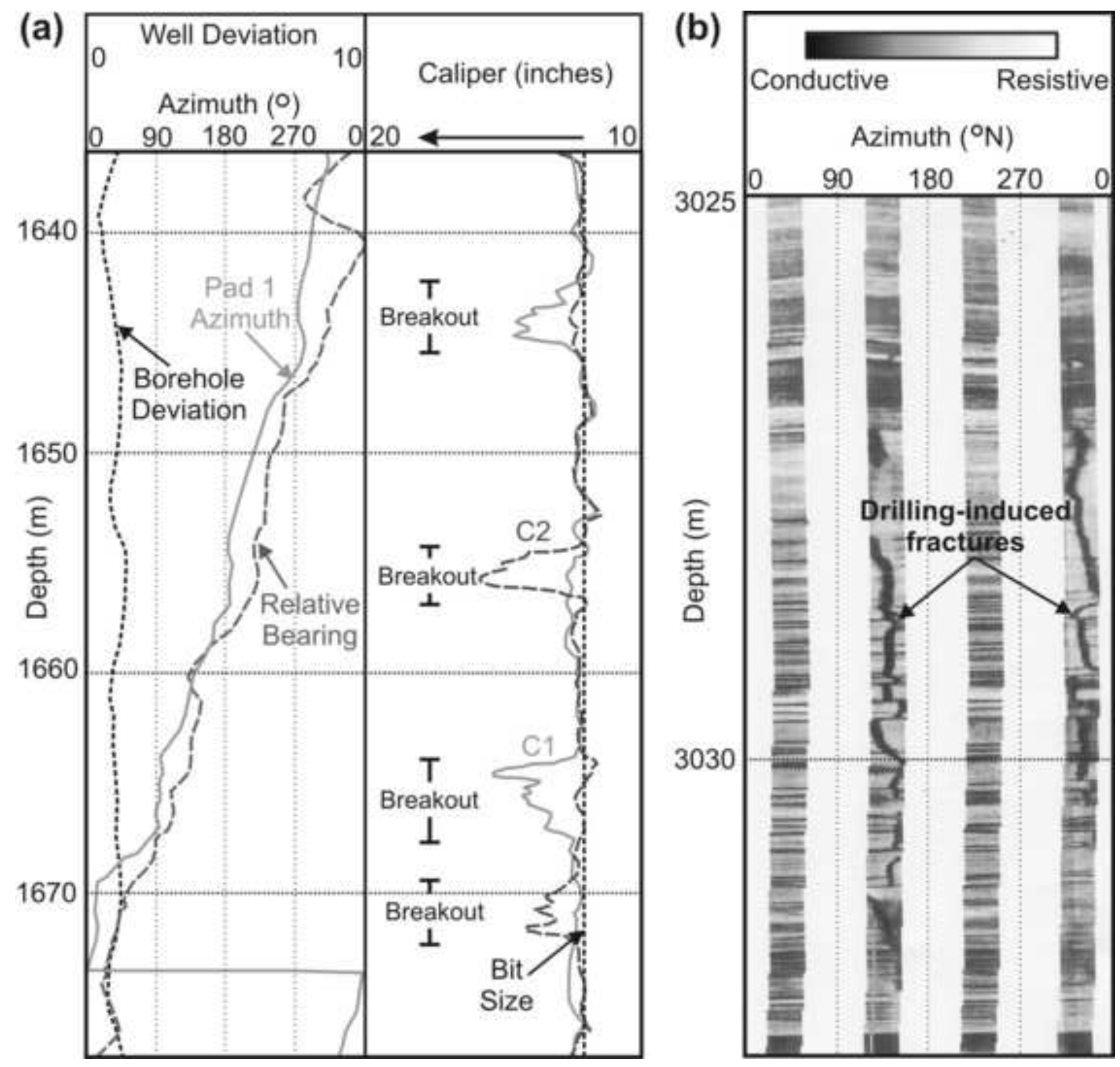


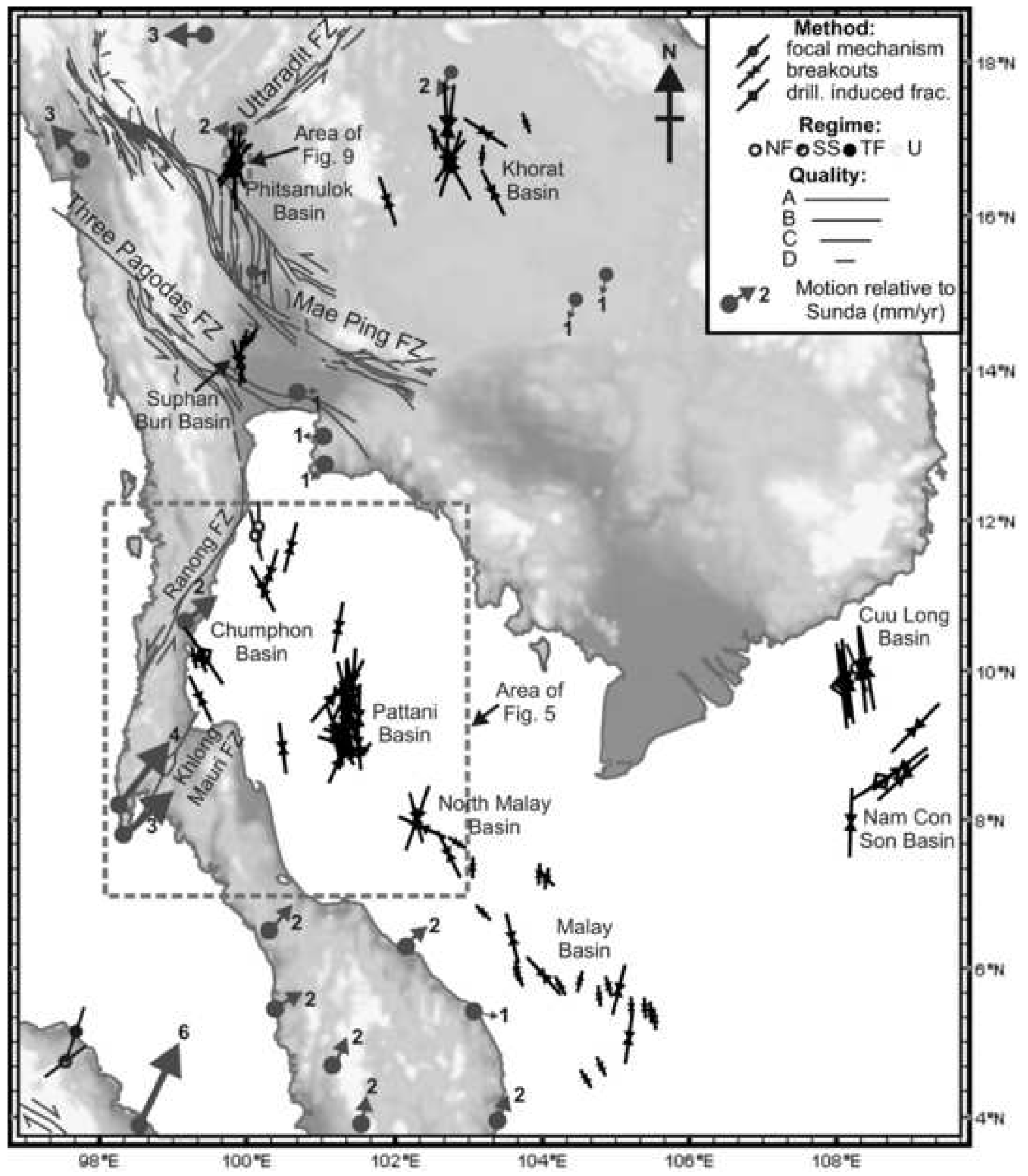




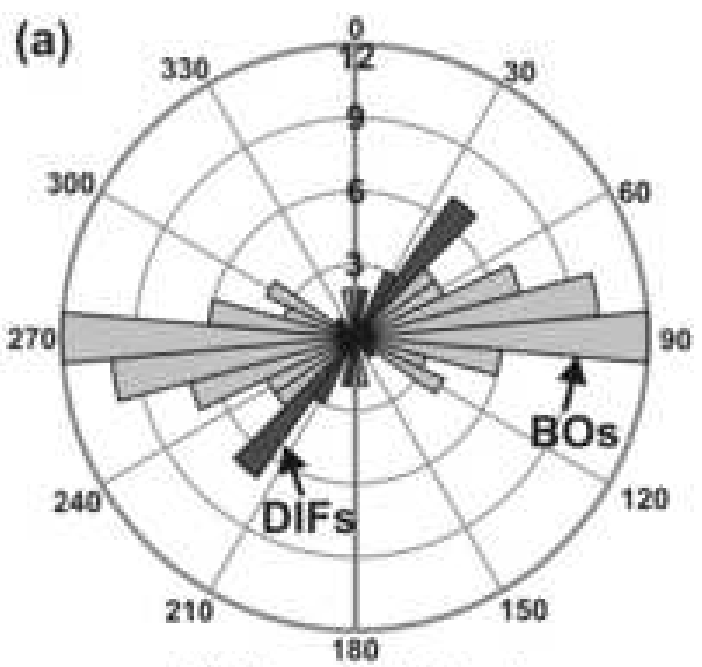

Phitsanulok Basin

Ave. $S_{\text {timax }}$ Azi $=005^{\circ} ;$ S.D $=25^{\circ}$

$54 \mathrm{BOs}, 12$ DIFs; $\mathrm{L}=1270 \mathrm{~m}$

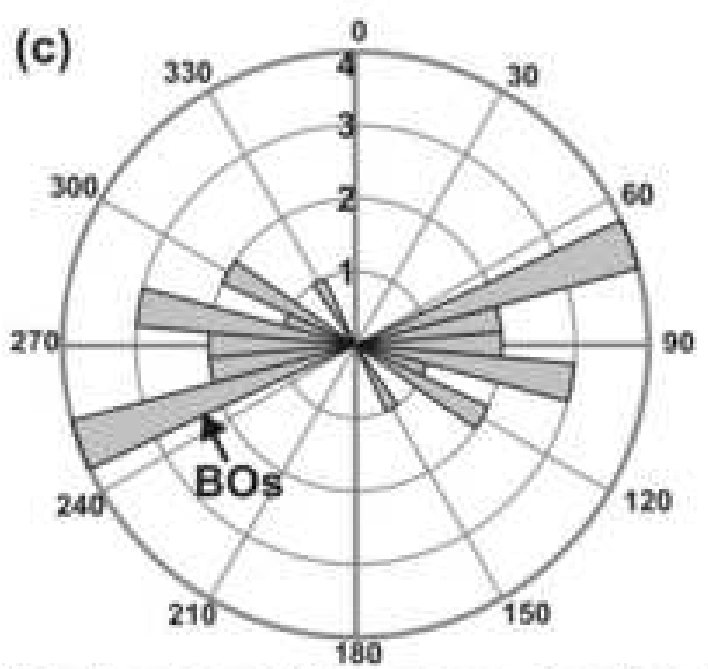

Suphan Buri/Khampaeng San Basin Ave. $S_{\min } A z i=001^{\circ} ; S . D=23^{\circ}$ 15 BOs; $L=292 \mathrm{~m}$

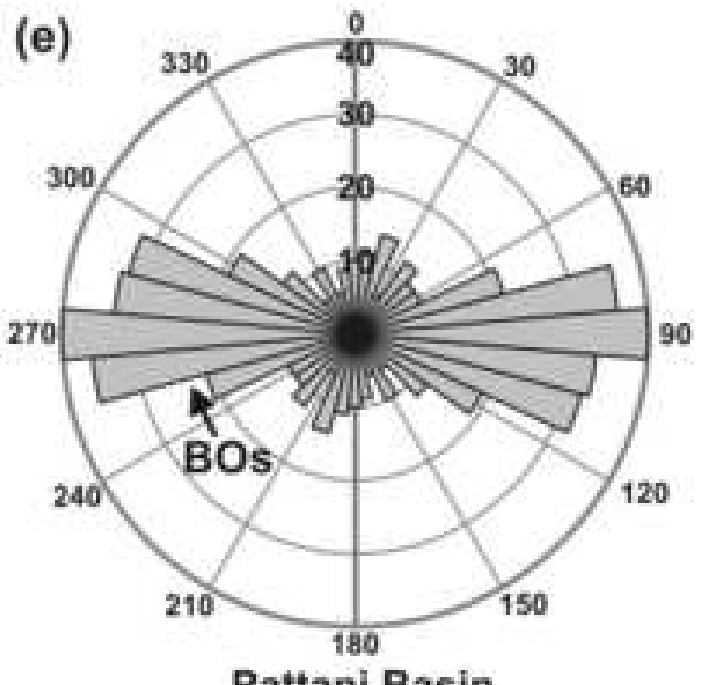

Pattani Basin

Ave. $S_{\text {timax }} A z i=000^{\circ} ; S . D=40^{\circ}$ $297 \mathrm{BOs} ; \mathrm{L}=8470 \mathrm{~m}$

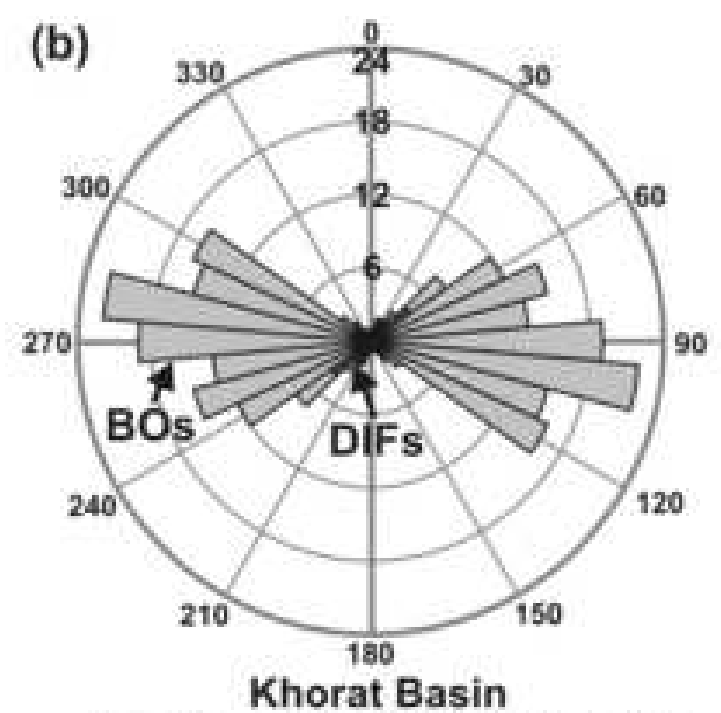

Ave. $S_{\text {tmax }} A z i=000^{\circ} ; S \cdot D=26^{\circ}$ $130 \mathrm{BOs}, 12$ DIFs; $\mathrm{L}=1504 \mathrm{~m}$

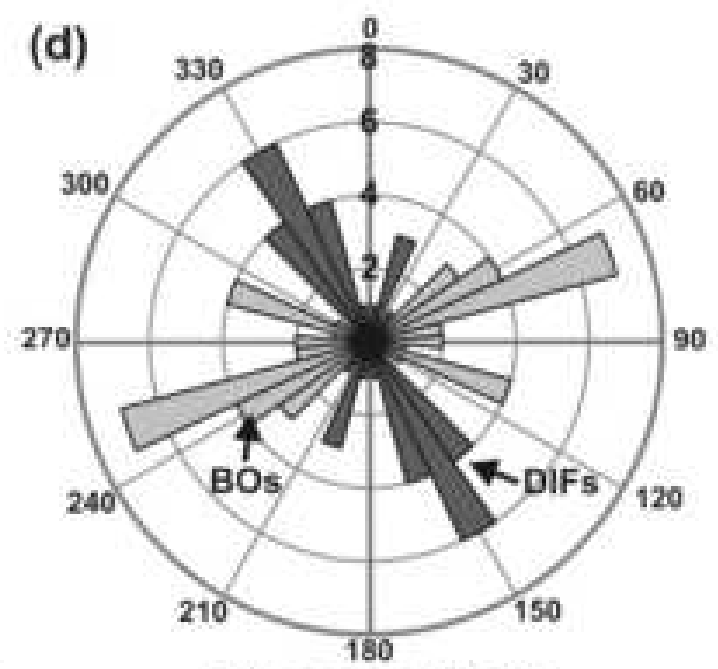

Chumphon Basin

Ave. $S_{\text {, }} A z i=161^{\circ} ; S \cdot D=23^{\circ}$

24 BOs, 21 DIFs; L = $167 \mathrm{~m}$

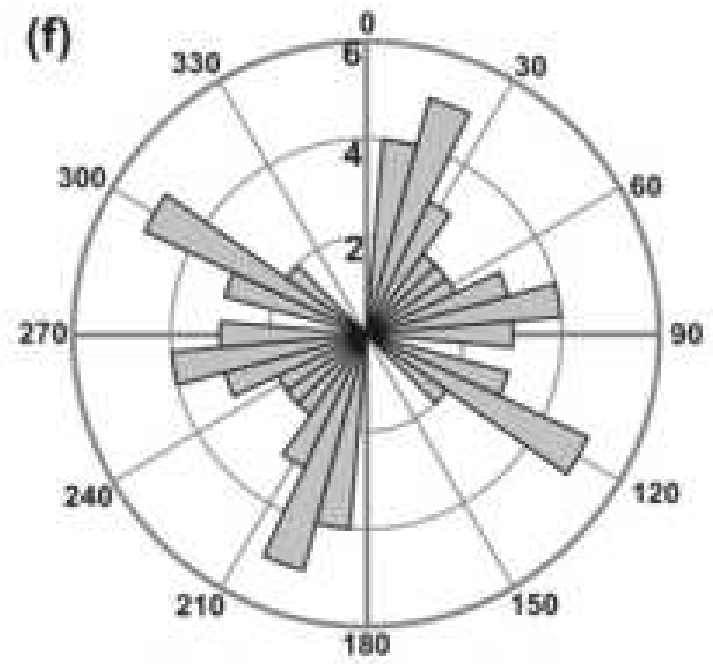

Northern Malay Basin

Ave. $S_{\max } A z i=153^{\circ} ; S . D=45^{\circ}$

38 BOs; $L=382 \mathrm{~m}$ 
Click here to download high resolution image

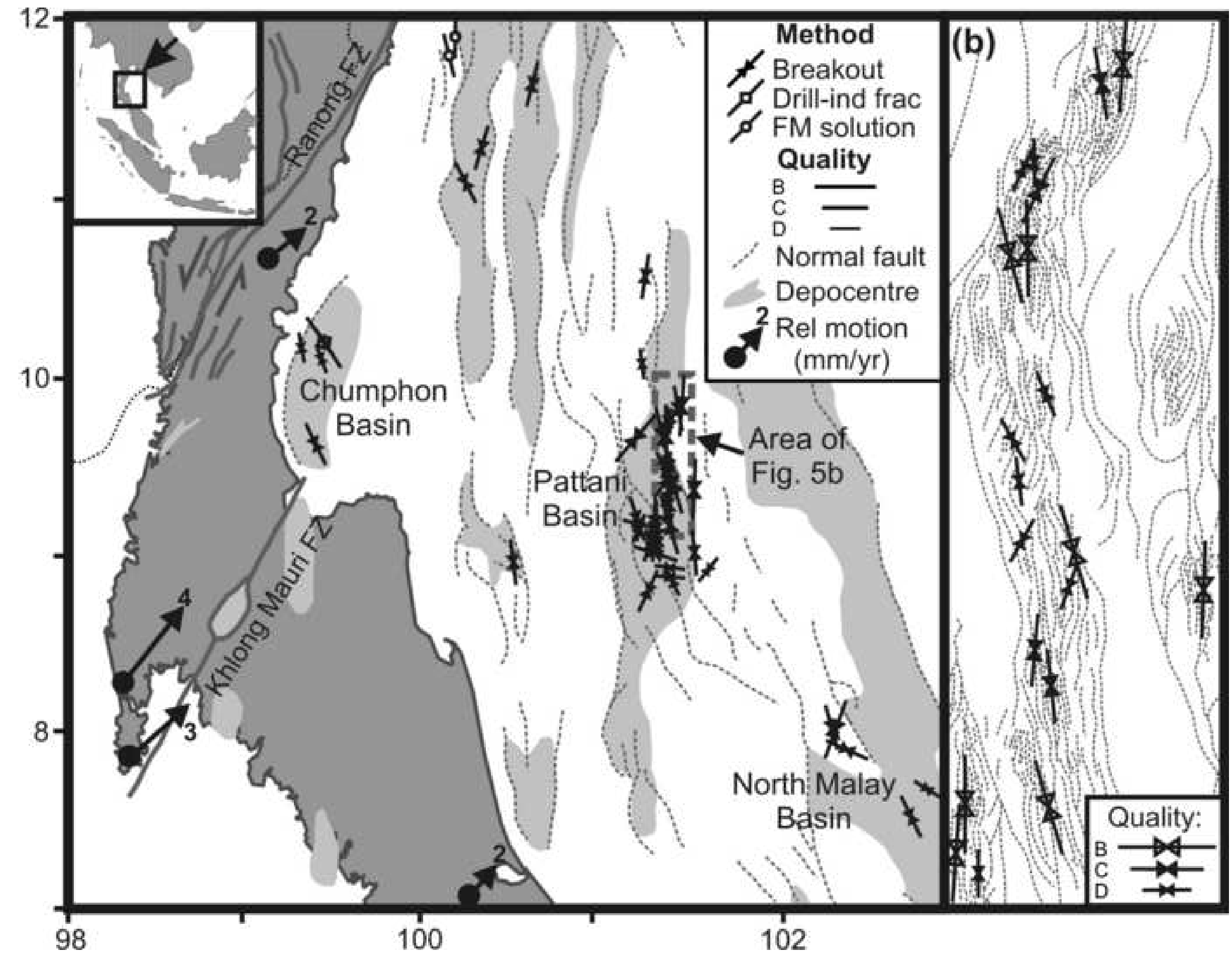


Figure 6

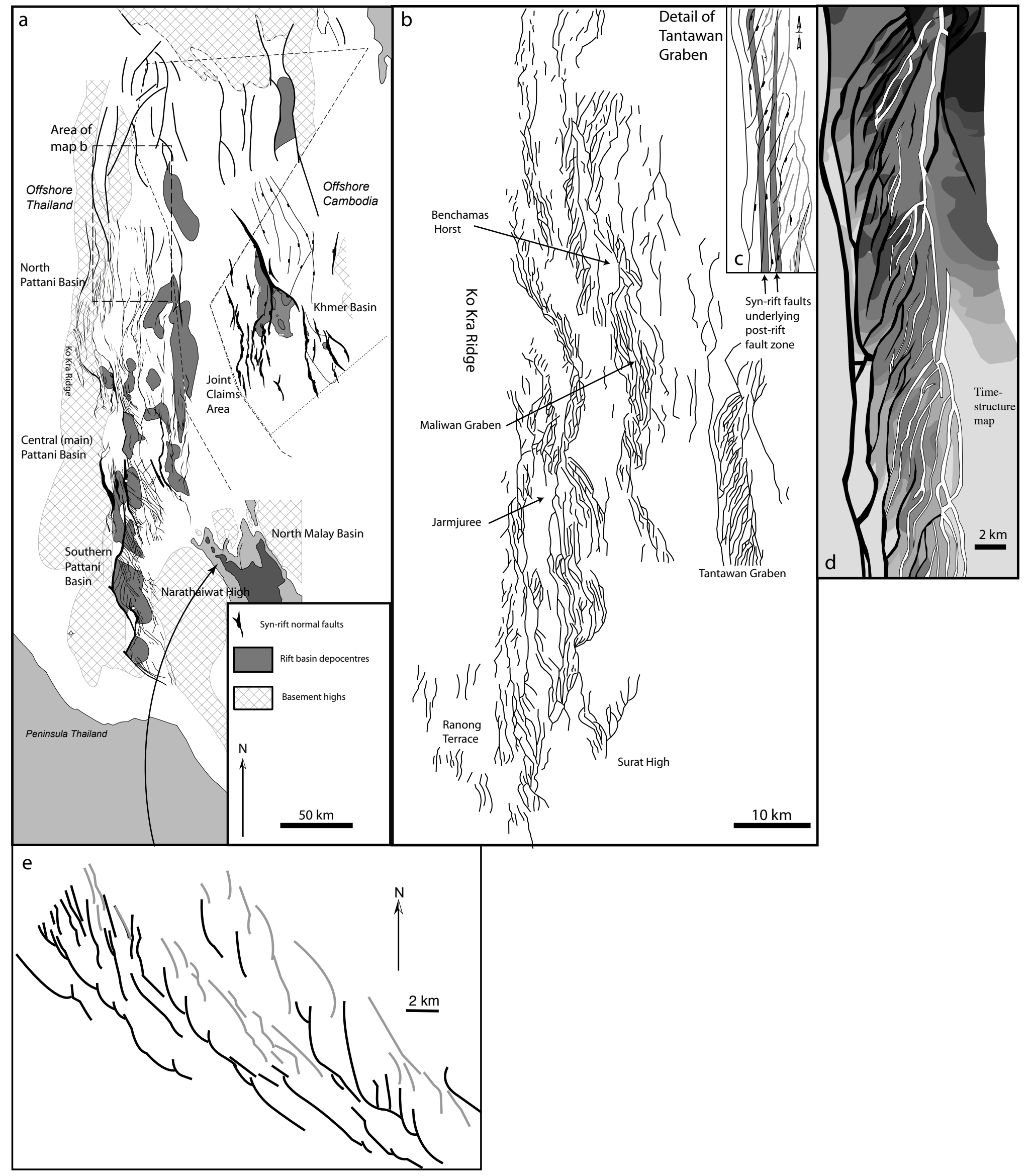


Figure 7

Post-rift fault trends curve from $\mathrm{N}-\mathrm{S}$ to NW-SW to follow the trend of an underlying syn-rift fault

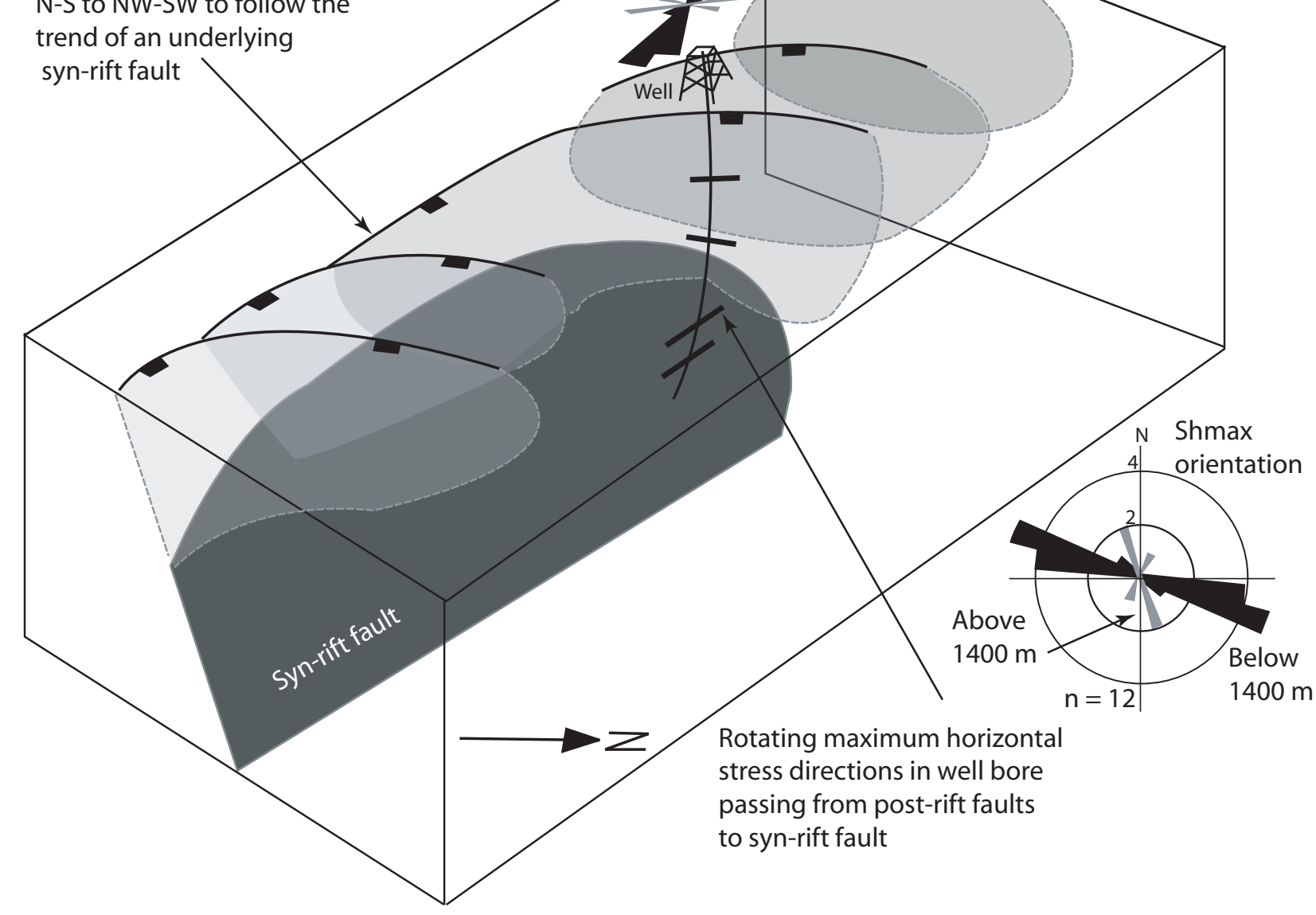


Figure 8

Click here to download high resolution image

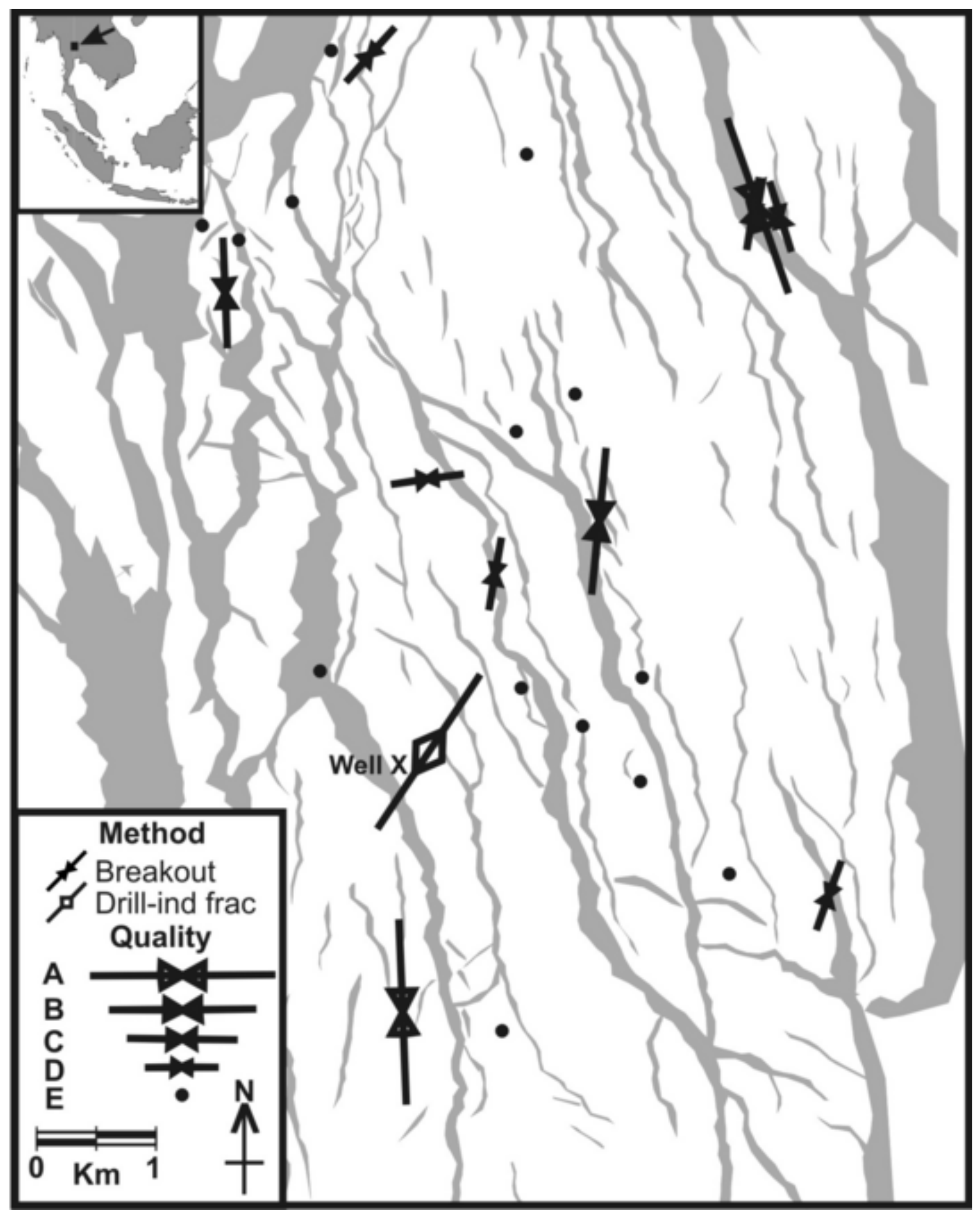


Figure 9

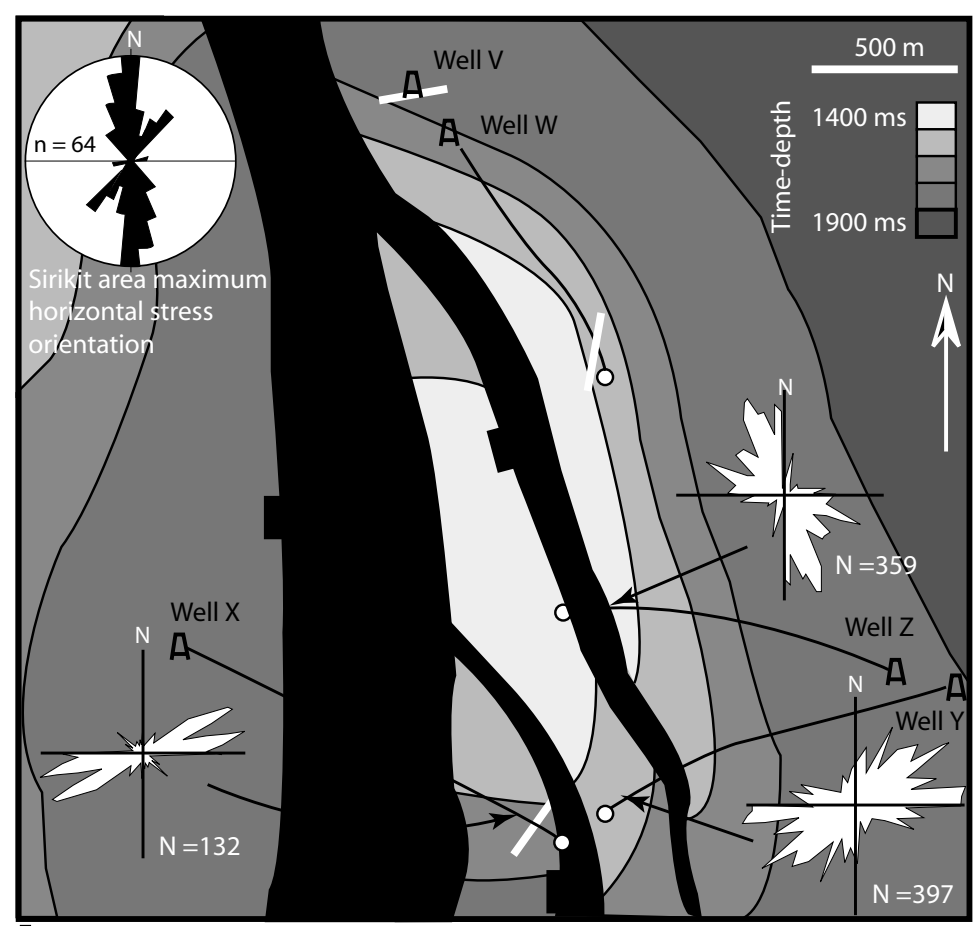

Well location at surfac Well path

$\delta$ Well location at final

Maximum horizontal

Open fracture (total) depth

stress direction

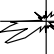

B orientations 